\title{
Genome-Wide Meta-Analysis of Late-Onset Alzheimer's Disease Using Rare Variant Imputation in 65,602 Subjects Identifies Novel Rare Variant Locus NCK2: The International Genomics of Alzheimer's Project (IGAP)
}

Adam C. Naj ${ }^{1,2 * \#}$, Ganna Leonenko ${ }^{3 *}$, Xueqiu Jian ${ }^{4 *}$, Benjamin Grenier-Boley ${ }^{5 *}$, Maria Carolina Dalmasso ${ }^{6 *}$, Celine Bellenguez ${ }^{5 *}$, Jin Sha ${ }^{1}$, Yi Zhao ${ }^{2}$, Sven J. van der Lee ${ }^{7}$, Rebecca Sims $^{8}$, Vincent Chouraki ${ }^{5}$, Joshua C. Bis ${ }^{9}$, Brian W. Kunkle ${ }^{10,11}$, Peter Holmans ${ }^{8}$, Yuk Yee Leung $^{2}$, John J. Farrell ${ }^{12}$, Alessandra Chesi ${ }^{2}$, Hung-Hsin Chen ${ }^{13}$, Badri Vardarajan ${ }^{14}$, Penelope Benchek $^{15}$, Sandral Barral ${ }^{14}$, Chien-Yueh Lee ${ }^{2}$, Pavel Kuksa ${ }^{2}$, Jacob Haut ${ }^{1}$, Edward B. Lee ${ }^{2,16}$, Mingyao Li $^{1}$, Yuanchao Zhang ${ }^{1}$, Struan Grant ${ }^{17,18}$, Jennifer E. Phillips-Cremins ${ }^{19}$, Hata Comic ${ }^{20}$, Achilleas Pitsillides ${ }^{21}$, Rui Xia ${ }^{22}$, Kara L. Hamilton-Nelson ${ }^{10}$, Amanda Kuzma ${ }^{2}$, Otto Valladares $^{2}$, Brian Fulton-Howard ${ }^{23}$, Josee Dupuis ${ }^{21}$, Will S. Bush ${ }^{15}$, Li-San Wang ${ }^{2}$, Jennifer E. Below $^{13}$, Lindsay A. Farrer ${ }^{12,21,24}$, Cornelia van Duijn ${ }^{20,25}$, Richard Mayeux ${ }^{14}$, Jonathan L. Haines $^{15}$, Anita L. DeStefano ${ }^{21}$, Margaret A. Pericak-Vance ${ }^{10,11}$, Alfredo Ramirez ${ }^{6 *}$, Sudha Seshadri $^{27 * *}$, Philippe Amouyel ${ }^{5 * *}$, Julie Williams $^{8 * *}$, Jean-Charles Lambert ${ }^{5 * *}$, and Gerard D. Schellenberg $2 * *$

\section{(Group authorship currently under revision.)}

On behalf of the International Genomics of Alzheimer's Project (IGAP)

* Co-first authors

** Co-senior authors

\# Corresponding author

${ }^{1}$ Department of Biostatistics, Epidemiology, and Informatics, and

${ }^{2}$ Department of Pathology and Laboratory Medicine, Perelman School of Medicine, University of Pennsylvania, Philadelphia, PA, USA;

${ }^{3}$ Division of Psychological Medicine and Clinical Neurosciences, School of Medicine, Cardiff University, Wales, UK;

${ }^{4}$ Brown Foundation Institute of Molecular Medicine, University of Texas Health Sciences Center at Houston, Houston, TX, USA;

${ }^{5}$ Inserm, CHU Lille, Institut Pasteur de Lille, U1167-RID-AGE Facteurs de risque et déterminants moléculaires des maladies liées au vieillissement, University of Lille, Lille, France;

${ }^{6}$ Department of Psychiatry \& Psychotherapy, University of Cologne, Cologne, Germany;

${ }^{7}$ Alzheimer Center, VU University Medical Center, Amsterdam, the Netherlands;

${ }^{8}$ Dementia Research Institute, School of Medicine, Cardiff University, Wales, UK;

${ }^{9}$ Cardiovascular Health Research Unit, Department of Medicine, University of Washington, Seattle, WA, USA;

${ }^{10}$ John P. Hussman Institute for Human Genomics, Miller School of Medicine, University of Miami, Miami, FL, USA;

${ }^{11}$ Dr. John T. Macdonald Foundation, Department of Human Genetics, Miller School of Medicine, University of Miami, Miami, FL, USA;

${ }^{12}$ Department of Medicine (Biomedical Genetics), Boston University School of Medicine, Boston, MA, USA;

${ }^{13}$ Vanderbilt Genetics Institute, Vanderbilt University Medical Center, Nashville, TN, USA;

${ }^{14}$ Taub Institute on Alzheimer's Disease and the Aging Brain, Department of Neurology; Gertrude H. Sergievsky Center; and Department of Neurology, Columbia University, New York, NY, USA. 
medRxiv preprint doi: https://doi.org/10.1101/2021.03.14.21253553; this version posted March 24, 2021. The copyright holder for this preprint (which was not certified by peer review) is the author/funder, who has granted medRxiv a license to display the preprint in perpetuity. It is made available under a CC-BY-NC-ND 4.0 International license .

IGAP HRC GWAS Meta-Analysis Naj et al.

\footnotetext{
${ }^{15}$ Department of Population \& Quantitative Health Sciences, School of Medicine, Case Western Reserve University, Cleveland, OH, USA;

${ }^{16}$ Translational Neuropathology Research Laboratory, Department of Pathology and Laboratory Medicine, Perelman School of Medicine, University of Pennsylvania, Philadelphia, PA, USA;

${ }^{17}$ Division of Human Genetics, The Children's Hospital of Philadelphia, 3615 Civic Center Boulevard, Philadelphia, PA, USA;

${ }^{18}$ Department of Genetics, Perelman School of Medicine, University of Pennsylvania, 3615 Civic Center Boulevard, Philadelphia, PA, USA;

${ }^{19}$ Department of Bioengineering, University of Pennsylvania, Philadelphia, PA, USA;

${ }^{20}$ Department of Epidemiology, Erasmus Medical Center, Rotterdam, the Netherlands;

${ }^{21}$ Department of Biostatistics, School of Public Health, Boston University, Boston, MA, USA;

${ }^{22} \mathrm{Imm}$ Center for Human Genetics, University of Texas Health Sciences Center at Houston, Houston, TX, USA;

${ }^{23}$ Ronald M. Loeb Center for Alzheimer's Disease, Mt. Sinai Icahn School od Medicine, New York, NY, USA;

${ }^{24}$ Department of Neurology, School of Medicine, Boston University, Boston, MA, USA;

${ }^{25}$ Nuffield Department of Population Health, St. Cross College, Oxford University, Oxford, England, UK;

${ }^{26}$ Department of Population \& Quantitative Health Sciences, School of Medicine, Case Western Reserve University, Cleveland, OH, USA;

${ }^{27}$ Glenn Biggs Institute for Alzheimer's \& Neurodegenerative Diseases, University of Texas Health Sciences

Center, San Antonio, TX, USA.
}

(Short Running Title: IGAP HRC Meta-analysis of GWAS)

\section{Address correspondence to:}

Adam Naj, PhD

Assistant Professor of Epidemiology, Department of Biostatistics, Epidemiology, and

Informatics (DBEI) and Department of Pathology and Laboratory Medicine

University of Pennsylvania Perelman School of Medicine

229 Blockley Hall

423 Guardian Drive

Philadelphia, PA 19107

Phone: (215) 746-4180

Fax: (215) 573-1050

\section{Word Count: $\quad 7,771$ \\ Abstract: $\quad 233$ \\ Text: $\quad 7,538$}

Keywords: Genome-wide association studies (GWAS), GWAS Meta-Analysis, Late-Onset Alzheimer Disease (LOAD), functional genomics

Draft \#14

Date March 12, 2021 
medRxiv preprint doi: https://doi.org/10.1101/2021.03.14.21253553; this version posted March 24, 2021. The copyright holder for this preprint (which was not certified by peer review) is the author/funder, who has granted medRxiv a license to display the preprint in perpetuity. It is made available under a CC-BY-NC-ND 4.0 International license .

IGAP HRC GWAS Meta-Analysis Naj et al.

\section{Abstract}

Risk for late-onset Alzheimer's disease (LOAD) is driven by multiple loci primarily identified by genome-wide association studies, many of which are common variants with minor allele frequencies $(\mathrm{MAF})>0.01$. To identify additional common and rare LOAD risk variants, we performed a GWAS on 25,170 LOAD subjects and 41,052 cognitively normal controls in 44 datasets from the International Genomics of Alzheimer's Project (IGAP). Existing genotype data was imputed using the dense, high-resolution Haplotype Reference Consortium (HRC) r1.1 reference panel. Stage 1 associations of $P<10^{-5}$ were meta-analyzed with the European Alzheimer's Disease Biobank (EADB) ( $n=20,301$ cases; 21,839 controls) (stage 2 combined IGAP and EADB). An expanded meta-analysis was performed using a GWAS of parental AD/dementia history in the UK Biobank (UKBB) ( $\mathrm{n}=35,214$ cases; 180,791 controls) (stage 3 combined IGAP, EADB, and $\mathrm{UKBB})$. Common variant (MAF $\geq 0.01)$ associations were identified for 29 loci in stage 2, including novel genome-wide significant associations at TSPAN14 $\left(P=2.33 \times 10^{-12}\right), \operatorname{SHARPIN}$ $\left(P=1.56 \times 10^{-9}\right)$, and $A T F 5 / \operatorname{SIGLEC11}\left(P=1.03 \times 10^{-8}\right)$, and newly significant associations without using AD proxy cases in MTSSIL/IL34 $\left(P=1.80 \times 10^{-8}\right), A P H 1 B\left(P=2.10 \times 10^{-13}\right)$, and CLNK $\left(P=2.24 \times 10^{-10}\right)$. Rare variant $(\mathrm{MAF}<0.01)$ associations with genome-wide significance in stage 2 included multiple variants in $A P O E$ and TREM2, and a novel association of a rare variant (rs143080277; $\left.\mathrm{MAF}=0.0054 ; P=2.69 \times 10^{-9}\right)$ in $N C K 2$, further strengthened with the inclusion of UKBB data in stage $3\left(P=7.17 \times 10^{-13}\right)$. Single-nucleus sequence data shows that $N C K 2$ is highly expressed in amyloid-responsive microglial cells, suggesting a role in LOAD pathology. 
medRxiv preprint doi: https://doi.org/10.1101/2021.03.14.21253553; this version posted March 24, 2021. The copyright holder for this preprint (which was not certified by peer review) is the author/funder, who has granted medRxiv a license to display the preprint in perpetuity. It is made available under a CC-BY-NC-ND 4.0 International license .

IGAP HRC GWAS Meta-Analysis Naj et al.

\section{Introduction}

Alzheimer's disease (AD) is the most common neurodegenerative disease with an estimated 50 million persons affected globally. With the prevalence predicted to triple by 2050 , AD is an intensifying public health crisis requiring insight into key genetic and environmental risk contributors to guide the development of therapeutic interventions to prevent and treat the disease. The common form of the disease, late-onset $\mathrm{AD}$ (LOAD) accounts for $\sim 95 \%$ of all cases and is highly heritable $\left(h^{2} \sim 60-80 \%\right)^{1}$ and polygenic ${ }^{2}$. Previous genetic studies of LOAD including genome-wide association studies ${ }^{3-16}$ and more recently sequencing studies ${ }^{17-23}$ yielded confirmed associations at nearly 30 distinct $l o i^{24,25}$, including many common variants (minor allele frequency $[\mathrm{MAF}]>0.01)$ and more recently rare variants $(\mathrm{MAF} \leq 0.01)$ in $A P P^{26}, T R E M 2^{27,28}$, $P L C G 2^{11}, A B I 3^{11}, S O R L 1^{17,29}$, and $A B C A 7^{30-32}$. While whole genome sequencing (WGS) studies can identify novel rare variants and private mutations in families enriched for disease ${ }^{33,34}$, current LOAD WGS study samples sizes are much smaller than available GWAS samples ${ }^{34}$, limiting statistical power to detect genome-wide significant associations at many rare variants ${ }^{35}$. Highresolution imputation of rare and low frequency variation in large GWAS studies is a cost-effective alternative to de novo sequencing for identifying rare LOAD $\operatorname{loci}^{36}$.

This multi-stage LOAD GWAS incorporated genotype data from 109,973 cases and 285,418 controls from the International Genomics of Alzheimer's Project (IGAP; Stage 1), European Alzheimer's Disease Biobank ${ }^{37}$ (EADB; IGAP+EADB, Stage 2), and the UK Biobank (UKBB: IGAP+EADB+UKBB, Stage 3), imputed using the Haplotype Reference Consortium (HRC) r1.1 (IGAP and UKBB) or the Trans-Omics for Precision Medicine (TOPMed) Freeze 5 panels (EADB). We also explored the association and potential functional roles of these imputed variants with function-informed analyses including genetically-regulated gene expression and co- 
medRxiv preprint doi: https://doi.org/10.1101/2021.03.14.21253553; this version posted March 24, 2021. The copyright holder for this preprint (which was not certified by peer review) is the author/funder, who has granted medRxiv a license to display the preprint in perpetuity. It is made available under a CC-BY-NC-ND 4.0 International license .

IGAP HRC GWAS Meta-Analysis Naj et al.

expression analyses. Furthermore, we applied functional genomics approaches to characterize potential roles of identified variants at the chromatin level and on the cellular level in AD pathogenesis.

\section{Results}

Study Design and Participant Characteristics. We conducted a discovery meta-analysis (Stage 1) of 44 GWAS datasets of non-Hispanic Whites (NHW) subjects [n=25,170 cases; 41,052 cognitively normal elders] in the IGAP. IGAP comprises data from five consortia including the Alzheimer's Disease Genetics Consortium (ADGC), the Cohorts for Heart and Aging Research in Genomic Epidemiology Consortium (CHARGE), the European Alzheimer's Disease Initiative (EADI), and Genetic and Environmental Risk in AD/Defining Genetic, Polygenic and Environmental Risk for Alzheimer's Disease Consortium (GERAD/PERADES) and a dataset from the University of Bonn (BONN) (cohort details in the Supplementary Note and Supplementary Table 1). We validated Stage 1 suggestive associations of $P<10^{-5}$ in IGAP by meta-analysis with association results from the EADB $[n=20,301$ cases; 21,839 cognitively normal elders] (Stage 2). Additionally, we performed secondary replication in an AD/dementia family history GWAS in the UKBB using 35,214 'proxy cases' (defined as individuals reporting a history of $\mathrm{AD} /$ dementia in one or both parents and with age $\geq 65$ years) and 180,791 'proxy controls' (individuals reporting no history of $\mathrm{AD} /$ dementia in either biological parent and with age $\geq 65$ years). Stage 3 was a meta-analysis of IGAP, EADB, and UKBB findings for variants associated with $P<10^{-5}$ in IGAP. Analytic methods for the EADB replication and the UKBB secondary replication dataset are also in the Supplementary Note. The structure of the analyses is depicted in Figure 1. 
medRxiv preprint doi: https://doi.org/10.1101/2021.03.14.21253553; this version posted March 24, 2021. The copyright holder for this preprint (which was not certified by peer review) is the author/funder, who has granted medRxiv a license to display the preprint in perpetuity. It is made available under a CC-BY-NC-ND 4.0 International license .

IGAP HRC GWAS Meta-Analysis Naj et al.

IGAP, EADB, and UKBB all included a similar proportion of more females than males (IGAP, 60.3\% female; EADB, 59.4\%; UKBB, 55.2\%). Mean ages-at-onset among LOAD cases were 74.6 and 71.1 years for IGAP and EADB, respectively, with a higher onset age for the CHARGE cohorts (mean \pm SD: 83.6 \pm 1.1 ). Average ages-at-last-exam were later among IGAP cognitively normal controls (mean $\pm \mathrm{SD}: 77.4 \pm 6.4$ ) than $\mathrm{EADB}$ (mean $\pm \mathrm{SD}: 66.9 \pm 14.3$ ). $A P O E$ $\varepsilon 4$ frequencies in IGAP were $35.1 \%$ and $13.2 \%$ among cases and controls, respectively, while in EADB, they were similarly $32.6 \%$ among cases and $13.2 \%$ among controls.

Association Analysis of Common Variants (MAF>0.01). In Stage 1 (IGAP analyses), the strongest genome-wide association was observed as expected in the region around $A P O E$ on chromosome 19q13.32 (rs7259620; $P=2.25 \times 10^{-199} ;$ Table 1, Supplementary Table 2, Supplementary Figures 1 and 4). Fifteen loci outside of the $A P O E$ region yielded associations with genome-wide statistical significance $\left(P<5 \times 10^{-8}\right.$; GWS $)$ in Stage 1 analyses, including variants at loci observed in prior GWAS: BIN1, PICALM, CR1, the MS4A region, CLU, SORL1, CD2AP, ABCA7, USP6NL/ECHDC3, SLC24A4, SPI1, PTK2B, IQCK, and NYAP1. Two loci newly significant in IGAP were TSPOASP1-AS1 on chromosome $17 \mathrm{q} 22\left(\mathrm{rs} 2526377, P=5.90 \times 10^{-9}\right)$ and HBEGF on chromosome $5 \mathrm{q} 31.3\left(\mathrm{rs} 11168036, P=1.95 \times 10^{-8}\right)$.

For Stage 2, we meta-analyzed data on all variants in IGAP meeting our discovery threshold $\left(P<10^{-5} ; 3,345\right.$ variants $)$ in Stage 1 with associations of those variants in EADB. Although the most significantly associated variants changed at many loci, Stage 2 GWS associations (Table 2, Supplementary Table 2) included all Stage 1 GWS loci. GWS associations were observed in Stage 2 at known AD loci ADAMTS1, EPHA1, HLA-DRB1/5, SPI1, SORL1, IQCK, NME8, ACE, and UNC5CL/OARD1, and at several novel loci, including TSPAN14 (rs6586028, 2.33 $\left.\times 10^{-12}\right)$, SHARPIN (rs34173062, $\left.P=1.56 \times 10^{-9}\right)$, and ATF5/SIGLEC11 (rs875121, 
medRxiv preprint doi: https://doi.org/10.1101/2021.03.14.21253553; this version posted March 24, 2021. The copyright holder for this preprint (which was not certified by peer review) is the author/funder, who has granted medRxiv a license to display the preprint in perpetuity. It is made available under a CC-BY-NC-ND 4.0 International license .

IGAP HRC GWAS Meta-Analysis Naj et al.

$\left.P=1.03 \times 10^{-8}\right)$. Several loci that had been observed in studies mixing proxy cases and controls with clinically- and pathologically-defined cases and controls were now observed to be associated in data without proxy cases/controls, including $A P H 1 B$ (rs117618017, $P=2.10 \times 10^{-13}$ ), CLNK (rs2904297, $\left.P=1.20 \times 10^{-10}\right)$, and MTSS1L/IL34 (rs11538963, $\left.P=7.80 \times 10^{-9}\right)$,

For stage 3, we meta-analyzed IGAP and EADB with the UKBB parental history GWAS (Table 2, Supplementary Table 2). Although parental history of dementia/AD is predictive of dementia in later life ${ }^{38-40}$, the lower precision of this phenotype as a proxy for the clinical/neuropathologic AD phenotypes in IGAP and EADB likely resulted in more heterogeneity and smaller effect sizes among the associations observed in UKBB compared to IGAP and EADB without applying any corrective factors. We considered an association replicated in the UKBB data if there was nominal statistical significance $(P<0.05)$ and the effect direction was consistent with Stage 1 and 2 results. Replication was obtained for associations in the APOE Region, BIN1, PICALM, CR1, the MS4A region, CLU, CD2AP, ABCA7, USP6NL/ECHDC3, SLC24A4, TSPOAP1-AS1, PTK2B, NYAP1, CASS4, EPHA1, NME8, ACE, and UNC5CL/OARD1. Several of the novel loci demonstrated GWS association in Stage 3, including TSPAN14 (rs6586028, $\left.P=5.74 \times 10^{-12}\right), C L N K\left(\mathrm{rs} 2904297, P=1.92 \times 10^{-13}\right), \operatorname{SHARPIN}\left(\mathrm{rs} 34173062, P=2.67 \times 10^{-13}\right), A P H 1 B$ (rs117618017, $\left.P=9.62 \times 10^{-13}\right)$, and $A T F 5 / S I G L E C 11\left(\right.$ rs3896609, $\left.P=4.84 \times 10^{-9}\right)$.

We also analyzed the UKBB data alone as a GWAS of parental history of AD/dementia to compare patterns of association between $\mathrm{AD}$ and $\mathrm{AD}$ proxy phenotypes. GWS common variant associations (Supplementary Tables 3 and 4) included signals in or around known susceptibility loci such as $A P O E, B I N 1, N Y A P 1 / P I L R B$, and $H L A-D R B 1$, as well as an association near $\operatorname{VKORC1/BCKDK}\left(P=3.82 \times 10^{-8}\right)$, which was observed in the Schwarzentruber AD family history analysis $^{41}$ and reported as KAT8 in the Jansen et al. study ${ }^{13}$ which also included UKBB 
medRxiv preprint doi: https://doi.org/10.1101/2021.03.14.21253553; this version posted March 24, 2021. The copyright holder for this preprint (which was not certified by peer review) is the author/funder, who has granted medRxiv a license to display the preprint in perpetuity. It is made available under a CC-BY-NC-ND 4.0 International license .

IGAP HRC GWAS Meta-Analysis Naj et al.

$\mathrm{AD} /$ dementia family history data. Discovery-level associations $\left(P<10^{-5}\right)$ were observed for several known $\mathrm{AD}$ susceptibility loci, including $A B C A 7$, PICALM, MS4A Region, ADAM10/MINDY2, EPHA1, and CR1. We followed up UKBB associations with $P<10^{-5}$ by meta-analysis with IGAP data and identified a GWS association at EPHX2 (rs7341557, $\left.P=5.33 \times 10^{-11}\right)$ (Supplementary Tables 3 and 4), although it is unclear if this is independent of common variant associations at proximal loci $C L U$ and $P T K 2 B$.

Association Analysis of Rare Variants $(M A F \leq 0.01)$. Stage 1 analysis of rare variants (Table 3, Supplementary Table 5, Supplementary Figures 2 and 5) identified 22 variants at 12 distinct genomic regions with associations of discovery-level significance $\left(P<10^{-5}\right)$ for further follow-up. In addition to multiple associations in the $A P O E$ region and in/around TREM2, novel signals attaining discovery-level significance were present in/around the genes $R O R A, N C K 2$, LINC02033/TRANK1, DYTN/MDH1B, ZBTB10/ZNF704, CNTNAP4, ODC1/NOL10, LINC00320, $E P H A 3$, and $C C D C 102 B$, though only $A P O E$ region and TREM2 were GWS.

Stage 2 associations (Table 4, Supplementary Table 5) meta-analyzing IGAP and EADB revealed one novel GWS association at the chromosome 2q12.2 gene NCK2 (rs143080277; Stage 2: $\mathrm{MAF}=0.0054, \mathrm{OR}[95 \% \mathrm{CI}]: 1.48[1.29,1.70], P=2.69 \times 10^{-8}$; IGAP: MAF=0.0052, OR[95\% $\mathrm{CI}]: 1.65[1.36,2.01], P=3.66 \times 10^{-7}$; $\mathrm{EADB}: \mathrm{MAF}=0.0056, \mathrm{OR}[95 \% \mathrm{CI}]: 1.32[1.08,1.61]$, $P=0.00576)$.

Stage 3 meta-analyses (Supplementary Table 5) greatly strengthened the association at the NCK2 variant rs143080277, (Stage 3: $\mathrm{MAF}=0.0048, \mathrm{OR}[95 \% \mathrm{CI}]: 1.40[1.28,1.54]$, $P=7.17 \times 10^{-13}$; UKBB: MAF=0.0041, OR[95\% CI]: $\left.1.34[1.18,1.52], P=3.22 \times 10^{-6}\right)$. Since these NCK2 associations were inferred from imputed genotypes, we used Sanger sequencing to independently validate imputed genotypes. Assigning genotypes where imputation probabilities 
medRxiv preprint doi: https://doi.org/10.1101/2021.03.14.21253553; this version posted March 24, 2021. The copyright holder for this preprint (which was not certified by peer review) is the author/funder, who has granted medRxiv a license to display the preprint in perpetuity. It is made available under a CC-BY-NC-ND 4.0 International license .

IGAP HRC GWAS Meta-Analysis Naj et al.

were $>0.9$, we observed $98 \%$ agreement ( $98 \%$ sensitivity and specificity for the minor allele) between imputed and directly observed genotypes $(n=127$ samples sequenced, $50 \%$ predicted referent homozygotes and 50\% predicted heterozygous carriers).

Rare variant association analysis in the UKBB parental history of dementia/AD GWAS identified novel associations in the chromosome 16p13.12 gene MRTFB (rs149416930, $P=1.94 \times 10^{-8}$ ) and on chromosome 12p12.1 near the genes AC019209.2/MIR4302/RASSF $\left(\right.$ rs148024771, $\left.P=3.89 \times 10^{-8}\right)($ Supplementary Tables 6 and 7$)$.

We performed several follow-up analyses in the ADGC data on all APOE, TREM2, and NCK2 associations to determine if they were independent from known associations in $A P O E$ (the common risk-increasing $\varepsilon 4$ and rarer protective $\varepsilon 2$ haplotypes) and in TREM2 (R47H and R62H). For rare $A P O E$ region variants, adjustment for only $A P O E \varepsilon 2$ did not substantially reduce the association observed for any of the variants but after adjustment for both $A P O E \varepsilon 2$ and $\varepsilon 4$, main effects were no longer statistically significant (Supplementary Table 8a), suggesting the association is driven by correlation with $A P O E \varepsilon 4$. Similarly, for TREM2, variants adjustment for $\mathrm{R} 47 \mathrm{H}$ and $\mathrm{R} 62 \mathrm{H}$ saw a reduction in the association of all rare variants upstream of TREM2, suggesting those associations are correlated with existing signals at $\mathrm{R} 47 \mathrm{H}$ and $\mathrm{R} 62 \mathrm{H}$ (Supplementary Table 8b). Separately modeling covariate adjustment for $A P O E \varepsilon 2$ and TREM2 $\mathrm{R} 47 \mathrm{H}$, the strength of the association NCK2 SNP rs143080277 was not substantially changed. We also tested statistical interaction between rs143080277 and TREM2 R47H and also between rs143080277 and $A P O E \varepsilon 2$; the main effects of the $N C K 2$ variant in these models were not substantially changed, suggesting the $N C K 2$ variant remains largely independent of $A P O E \varepsilon 2$ and TREM2 R47H (Supplementary Table 8c). We also examined NCK2 for common variant and other rare variant associations, and though a discovery-level association was observed in the 
medRxiv preprint doi: https://doi.org/10.1101/2021.03.14.21253553; this version posted March 24, 2021. The copyright holder for this preprint (which was not certified by peer review) is the author/funder, who has granted medRxiv a license to display the preprint in perpetuity. It is made available under a CC-BY-NC-ND 4.0 International license .

IGAP HRC GWAS Meta-Analysis Naj et al.

UKBB for a variant of $\mathrm{MAF}=0.022\left(\mathrm{rs} 17269688, P=1.52 \times 10^{-6}\right)$, no $N C K 2$ variants other than rs 143080277 had discovery-level associations in IGAP (Stage 1) (data not shown).

Re-analysis with weighted AD/dementia parental history GWAS statistics. In prior analyses of the $\mathrm{AD} /$ dementia family history phenotype, the $\beta$ and $\mathrm{SE}$ were doubled in order to account for the proxy phenotype being a measure of the reported $\mathrm{AD} /$ dementia affection status of two parents. We re-analyzed the Stage 1-3 common variant and rare variant analyses using a doubled $\beta$ and SE to examine potential strengthened associations. For common variants, several loci which attained GWS in Stage 2 but not in Stage 3 were GWS in Stage 3 re-analysis (Supplementary Table 9a), including ADAMTS1 (rs2830500, $P=3.98 \times 10^{-10}$ ), SPI1 (rs11039202, $\left.P=2.88 \times 10^{-9}\right), S O R L 1\left(\mathrm{rs} 3781831, P=2.85 \times 10^{-10}\right), U S P 50[$ near $S P P L 2 A]\left(\mathrm{rs} 3131610, P=1.35 \times 10^{-}\right.$ ${ }^{8}$ ) and $\operatorname{IQCK}\left(\mathrm{rs} 9926151, P=3.61 \times 10^{-8}\right)$. In addition, a newly GWS association was observed in Stage 3 for a variant in EIF4G3 (rs12407731, $\left.P=2.36 \times 10^{-8}\right)$. For rare variants, while the level of significance for most variants increased, no additional loci demonstrated GWS in Stage 3 reanalysis (Supplementary Table 9b), only the rare variants at APOE, TREM2, and NCK2. Revisiting the UKBB common variant and rare variant discovery analyses (Supplementary Tables 9c and 9d, respectively), no additional variants demonstrated GWS in the UKBB + IGAP meta-analysis.

Gene-Based Association Analysis. Performing gene-based association testing on all rare variants (MAF $\leq 0.01)$ (Supplementary Table 10), we observed only Bonferroni-corrected statistically significant associations at $A P O E$ and TREM2. After applying additional filtering on CADD $C$-score predicted deleteriousness (Supplementary Table 11), again only $A P O E$ and TREM2 demonstrated association at Bonferroni-corrected significance thresholds at all three deleteriousness thresholds, $C \geq 5, C \geq 10$, and $C \geq 15$ and including variants with imputation $R^{2} \geq 0.3$, 
medRxiv preprint doi: https://doi.org/10.1101/2021.03.14.21253553; this version posted March 24, 2021. The copyright holder for this preprint (which was not certified by peer review) is the author/funder, who has granted medRxiv a license to display the preprint in perpetuity. It is made available under a CC-BY-NC-ND 4.0 International license .

IGAP HRC GWAS Meta-Analysis Naj et al.

We also examined gene-based association with MAGMA using common variants $(\mathrm{MAF}>0.01)$ within a $35 \mathrm{~kb}$ upstream (5') and $10 \mathrm{~kb}$ downstream (3') window around gene boundaries. Using a gene-based testing approach aggregating $P$-values for the most associated SNP and the mean SNP association ("P $P_{\text {multi }}$ "), we identified several gene associations meeting a Bonferroni-corrected threshold for significance for 19,427 genes tested $\left(\alpha=2.57 \times 10^{-6}\right)$ (Supplementary Table 12). In addition to associations at multiple genes in the $A P O E$ region, many genes containing GWS-associated SNPs from single-variant analyses were also strongly associated in gene-based analyses, including $C R 1 / C R 1 L, B I N 1$, multiple $M S 4 A$ region genes, $C L U$, PICALM, TREM2, CD2AP, SPI1, SORL1, IQCK, PTK2B, and HBEGF. Notably, multiple genes in the immediate vicinity of SPII on chromosome $11 \mathrm{p} 11.2$ demonstrated highly significant associations exceeding both GWS and Bonferroni-corrected thresholds in both single-variant and gene-based analyses, including the genes SLC39A13, MTCH2, PSMC3, FNBP4, NDUFS3, NUP160, RAPSN, AGBL2, PTPMT1, and MYBPC3.

Pathway Analysis. MAGMA-based pathway analyses using multiple annotation sources identified 30 distinct pathways with FDR-corrected associations of $Q<0.05$ when using gene-wide statistics from the MAGMA "multi" association model and a $35 \mathrm{~kb}$ upstream/10kb downstream window to assign SNPs to genes (Supplementary Table 13). These included more significant associations for LOAD pathologic processes identified in previous IGAP analyses ${ }^{12}$, such as both negative and positive regulation of APP protein catabolism (GO:1902991, GO:1902993), tau protein binding (GO:0048156), A $\beta$ formation (GO:1902003); pathways capturing cognitive processes, such as learning or memory (GO:0007611) and cognition (GO:0050890); and immunerelated pathways like those involving the MHC protein complex (GO:0042611). Examining the strongest gene-based associations among genes assigned to the 30 pathways with strongest 
medRxiv preprint doi: https://doi.org/10.1101/2021.03.14.21253553; this version posted March 24, 2021. The copyright holder for this preprint (which was not certified by peer review) is the author/funder, who has granted medRxiv a license to display the preprint in perpetuity. It is made available under a CC-BY-NC-ND 4.0 International license .

IGAP HRC GWAS Meta-Analysis Naj et al.

associations $(Q<0.05)$ in the MAGMA pathway analysis (Supplementary Table 14) identified multiple genes containing confirmed loci, including APOE, CLU, BIN1, PICALM, SORL1, $P T K 2 B$, and $A C E$, as well as several biological candidates including $S C A R A 3$, and SPII region genes such as NUP160 and PTPMT1.

Co-expression Analysis. MAGMA analyses ("multi” gene association module with a 35kb 5'/10kb 3' window) using co-expression modules from multiple sources (Supplementary Table 15) identified strong associations in modules from multiple sources that are enriched for immune response-related genes, some of which have considerable overlap with others (Gibbs:34, Gandal:CD11, Neueder:28, and Neueder:54) while others included distinct gene sets (Zhang:25). Two of the most strongly associated modules (Gibbs:34 and Gibbs:56), both previously correlated with $\mathrm{AD}^{42}$, were enriched for genes in the TYROBP causal network which relates to immune receptor binding on microglia, however none of the overlapping genes included GWAS signals or other known AD susceptibility loci.

The genes most strongly associated in the top co-expression modules (Neueder:28, Gibbs:34, Zhang:37, and Gandal:CD11) (Supplementary Table 16) include many genes containing top LOAD susceptibility loci from GWAS (several $A P O E$ region genes, MS4A4A/MS4A6A, PICALM, SPI1, TREM2, SORL1, SLC24A4, and ACE) as well as genes (RERE, PURA) implicated in AD pathology in functional or transcriptomic analyses ${ }^{43}$.

Analysis of Genetically Regulated Expression Using PrediXcan. We used PrediXcan to assess whether the variants (Supplementary Table 17a-b) and genes (Supplementary Table 17c-d) with discovery-level association $\left(P<10^{-5}\right.$ for variants; Bonferroni-corrected $\alpha$ thresholds for genes) were associated with expression patterns imputed using whole-body tissue transcriptome reference data from the GTEx Consortium (version 8). Looking at genes containing GWS variants, 
medRxiv preprint doi: https://doi.org/10.1101/2021.03.14.21253553; this version posted March 24, 2021. The copyright holder for this preprint (which was not certified by peer review) is the author/funder, who has granted medRxiv a license to display the preprint in perpetuity. It is made available under a CC-BY-NC-ND 4.0 International license .

IGAP HRC GWAS Meta-Analysis Naj et al.

we observed 137 genes associated with FDR-corrected $Q<0.05$ (Supplementary Table 17a) across a broad range of tissues, including brain region-specific associations with $C R 1$ and $C L U$ as well as multiple SPI1-region genes including MTCH2 and SLC39A13. Collapsing expression patterns across brain tissues (“cross-brain"), we observed brain-specific associations $(Q<0.05)$ in $A P O E$ region genes, $C L U, C R 1$, and $M S 4 A$ region genes (Supplementary Table 17b). Following up on 20 genes of interest from gene-based analyses, five genes met FDR-corrected $Q<0.05$ in preliminary analyses of expression of individual tissue types (Supplementary Table 17c), while six of the 20 genes had at least one significant association of FDR-corrected $Q<0.05$ with collapsed expression patterns across all tissues (“cross-all”) or "cross-brain" (Supplementary Table 17d): TOMM40, BCAM, PPPIR37, and CLASRP in the APOE region; PSMC3 in the vicinity of SPI1; and TREM2.

NCK2 Tissue-Specific Expression. The GWS variant rs143080277 is in the first intron of NCK2 (encoding the NCK adaptor protein 2; MIM: 604930). This gene is in a $743 \mathrm{~kb}$ topologically-associating domain (TAD) ${ }^{44}$ containing only three other genes, C2orf49, FHL2, and ECRG4 (C2orf40). Of these genes, only C2orf49 and NCK2 are expressed in multiple brain regions. NCK2 is also highly expressed in a variety of cell types including CD19+ B-Cells, CD4+ T cells, and CD8+ B cells (Supplementary Figure 6, data from BioGPS ${ }^{45}$ ). Single nuclei RNASeq of these genes show that NCK2 is selectively expressed in the AD-relevant cell type, microglia (Figure 2). We examined human cortex samples ${ }^{46}$ that included normal tissue without amyloid or tau aggregates (A-T-), tissue with amyloid only (A+T-) and tissue with both amyloid and tau aggregates $(\mathrm{A}+\mathrm{T}+)$. The highest expression was observed is in amyloid-responsive and homeostatic microglia in tau-negative regions $(\mathrm{A}+\mathrm{T}-)$. NCK2 expression in microglia is also influenced by TREM2 genotypes and is reduced in $\mathrm{R} 47 \mathrm{H}$ TREM2 carriers compared to the 
medRxiv preprint doi: https://doi.org/10.1101/2021.03.14.21253553; this version posted March 24, 2021. The copyright holder for this preprint (which was not certified by peer review) is the author/funder, who has granted medRxiv a license to display the preprint in perpetuity. It is made available under a CC-BY-NC-ND 4.0 International license .

IGAP HRC GWAS Meta-Analysis Naj et al.

wildtype genotype. Also, $N C K 2$ expression is reduced in $A P O E \varepsilon 4 / \varepsilon 4$ subjects compared to $A P O E$ $\varepsilon 3 / \varepsilon 3$ or $\varepsilon 3 / \varepsilon 4$. Both TREM2 and APOE are part of the microglial response triggered in AD.

Mapping Regulatory Roles and Chromatin Interactions of rs143080277/NCK2. The NCK2 variant rs143080277 falls within enhancer regions in 47 ROADMAP ${ }^{47}$ enhancer tracks, including tissues in four brain regions (dorsolateral prefrontal cortex, inferior temporal lobe, substantia nigra, and anterior caudate nucleus) and cell types including monocytes and $\mathrm{T}$ cells, among others. Analyzing Hi-C data ${ }^{48}$ from six human cell lines with ENCODE/ROADMAP functional genomic data, we found interactions between the rs 143080277 location and multiple other genomic regions, but not the promoter of NCK2 (Supplementary Figure 7). Using our high-resolution promoterfocused Capture C and ATAC-Seq database that includes $>40$ cell types and conditions ${ }^{49}$, we observed two enhancer-promoter interactions in follicular B helper T (TFH) cells ${ }^{50}$. One is a loop ( 390 kb) from this SNP to an open alternative promoter of a short isoform (NM_001253876.1) of UXS1 in TFH cells (Supplementary Figure 8a). The other contacted a closed alternative promoter of a short isoform (NM_001004720.3) of NCK2.

We also performed a more relaxed search in neural cell types only without requiring the SNP or the gene promoter to reside in open chromatin and investigating both the index SNP $(\operatorname{rs} 143080277)$ and a proxy SNP $\left(\operatorname{rs} 144636993 ; r^{2} \sim 0.5\left(D^{\prime}=1\right)\right.$ in the 1000 Genomes European [EUR] populations). One loop was observed between one loop between rs144636993 and an alternative promoter of the same short isoform (NM_001004720.3) of NCK2 in ESC-derived hypothalamic neurons ${ }^{51}$, however neither the SNP nor the promoter were found to be open (Supplementary Figure 8b).

\section{Discussion}


medRxiv preprint doi: https://doi.org/10.1101/2021.03.14.21253553; this version posted March 24, 2021. The copyright holder for this preprint (which was not certified by peer review) is the author/funder, who has granted medRxiv a license to display the preprint in perpetuity. It is made available under a CC-BY-NC-ND 4.0 International license .

IGAP HRC GWAS Meta-Analysis Naj et al.

In this study, we imputed rare variants using a high-density haplotype reference panel in a large collection of LOAD GWAS to identify novel associations with individual variants, genes, and gene sets, with the goal of further elucidating the genetic contributors to the pathology of this highly prevalent disease. We extended our genomic interrogation with functional genomics annotation and AD-relevant functional genomics resources including expression data and chromatin structure data to better characterize the role of novel variants we identified. This strategy proved effective in identifying a novel rare variant association with LOAD in the gene NCK2, rs143080277 (MAF=0.0054), which appears to alter expression patterns in amyloid-responsive microglia. Although more functional characterization is needed, this suggests a potential role in AD pathology worth additional exploration.

While little is understood about the specific role or roles NCK2 (encoding the NCK adaptor protein 2; MIM: 604930) may play in neurodegenerative processes, it is known to interact with a variety of genes/proteins that have already been implicated in AD (Supplementary Figure 9), including ephrins $(E F N B 1, E F N B 2, E F N B 3)$ [genes encoding ephrin receptors include known AD gene $E P H A 1]$; VLDLR, which encodes an ApoE receptor; and $I G F 1 R^{12}$.

Our exploratory functional work noted that the associated rs143080277 variant may perform a regulatory role in the expression of $N C K 2$ in brain tissues, and in particular amyloidresponsive microglia. Furthermore, our examination of differential expression patterns of NCK2 against $A P O E \varepsilon 2 / \varepsilon 3 / \varepsilon 4$ and TREM2 R47H backgrounds suggests that there may be some functional interactions with these major contributors to $\mathrm{AD}$ risk.

In addition to the novel rare variant association, we observed several novel common variant associations at APH1B, TSPAN14, CLNK, SHARPIN, MTSS1L/IL34, and ATF5/SIGLEC11 as well as the first ancestry-specific confirmatory GWS associations of TSPOASP1-AS1 and HBEGF, 
medRxiv preprint doi: https://doi.org/10.1101/2021.03.14.21253553; this version posted March 24, 2021. The copyright holder for this preprint (which was not certified by peer review) is the author/funder, who has granted medRxiv a license to display the preprint in perpetuity. It is made available under a CC-BY-NC-ND 4.0 International license .

IGAP HRC GWAS Meta-Analysis Naj et al.

which were previously observed in a multi-ethnic GWAS of LOAD ${ }^{52}$. Among the novel loci, TSPAN14, encoding tetraspanin 14, is one of a family of proteins involved in proteolytic processing of the amyloid precursor protein (APP) ${ }^{53}$ through physical interactions with APP secretases, and appears to regulate ADAM10 cleavage of substrates ${ }^{54}$, which may alter levels of A $\beta$ production $^{55}$. SHARPIN, which encodes Shank-associated RH domain-interacting protein, is a key regulator of neuroinflammatory response, stimulating macrophage activity and promoting $\mathrm{A} \beta$ phagocytosis in the presence of circulating $\mathrm{A} \beta^{56}$. A rare variant in SHARPIN have been shown to limit immune response ${ }^{57}$, which may promote LOAD development. ATF5, encoding activating transcription factor 5, and plays a critical regulatory role in neuronal development, downregulating differentiation of neuroprogenitor cells ${ }^{58}$. SIGLEC11 is a member of the sialic acid-binding, immunoglobulin-like lectin family, and Siglec-11 mediates anti-inflammatory activity and acts as an inhibitory receptor of inflammatory responses of microglia, potentially regulating microglial neurotoxivity ${ }^{59,60}$. Among the loci identified in previous studies which used proxy cases/controls, $A P H 1 B$, which encodes the Aph1B subunit of the $\gamma$-secretase complex, is critical to processing APP and inhibition or deletion of the subunit leads to reduced clearance of $A \beta^{61}$ and memory issues $^{62}$. MTSS1L, encoding metastasis suppressor 2 (formerly metastasis suppressor 1-like), is involved in plasma membrane dynamics. It is highly expressed in brain with modest or little expression in other tissues ${ }^{63}$. Though there is limited information on its potential role in Alzheimer's disease, whole exome sequencing in 143 consanguineous families identified variation in this gene associated with neurodegeneration ${ }^{64}$. Variants of MTSS1L have also been implicated in a spectrum of neurodevelopment-related phenotypes including global development delay ${ }^{65}$ and educational attainment ${ }^{66}$. IL34 encodes the cytokine Interleukin-34 ${ }^{67}$ which promotes the proliferation of microglia and clearance of soluble oligomeric $A \beta$, reducing neuronal damage in 
medRxiv preprint doi: https://doi.org/10.1101/2021.03.14.21253553; this version posted March 24, 2021. The copyright holder for this preprint (which was not certified by peer review) is the author/funder, who has granted medRxiv a license to display the preprint in perpetuity. It is made available under a CC-BY-NC-ND 4.0 International license .

IGAP HRC GWAS Meta-Analysis Naj et al.

$\mathrm{AD}^{68}$. CLNK encodes cytokine-dependent hematopoietic cell linker and is known to play a role in immunoreceptor-mediated signaling events. CLNK has been shown to interact, when phosphorylated, with $P L C G 2^{69}$. PLCG2 is a transmembrane signaling enzyme with critical regulatory functions in the immune system ${ }^{70}$ in which variation has been shown previously to be associated with $\mathrm{AD}^{11}$. While $C L N K$ has previously been identified in GWAS of family history of $\mathrm{AD}$ and studies mixing $\mathrm{AD}$ status with $\mathrm{AD} /$ dementia family history, this is first time GWS association with a pure AD phenotype has been observed at this locus.

The emerging LOAD loci confirmed in this analysis, TSPOAP1 and $H B E G F$, were both observed with GWS in a prior GWAS meta-analysis ${ }^{52}$ of 33,269 ADGC subjects, including 26,320 individuals of European ancestry, 4,983 African Americans, 1,845 Japanese subjects, and 115 Israeli-Arab participants). It should be noted that in a multi-ethnic study, allele frequencies and strength of association may be variable across ancestries; this study is the first time that these associations have been observed to attain genome-wide significance within ancestry among subjects of European ancestry, strengthening support for true association. That these loci were only observed as GWS in a single-ancestry sample of 80,685 cases and 243,682 controls of European ancestry, a study nearly 10 times larger than the multi-ethnic sample, reflects the power and utility of trans-ethnic meta-analyses in identifying novel loci over much larger ancestrally homogeneous data collections.

TSPOAP1 (formerly BZRAP1) encodes benzodiazepine-associated protein 1, a subunit of the benzodiazepine receptor complex in mitochondria, of which increased binding activity may indicate brain inflammation ${ }^{71-73}$. Additionally, benzodiazepine use has been shown to increase risk of dementia ${ }^{74} . H B E G F$, which encodes heparin EGF-like growth factor, has varied roles including cardiac hypertrophy and development ${ }^{75}$. Some functional work suggests that $H B E G F$ may have a 
medRxiv preprint doi: https://doi.org/10.1101/2021.03.14.21253553; this version posted March 24, 2021. The copyright holder for this preprint (which was not certified by peer review) is the author/funder, who has granted medRxiv a license to display the preprint in perpetuity. It is made available under a CC-BY-NC-ND 4.0 International license .

IGAP HRC GWAS Meta-Analysis Naj et al.

role in $\mathrm{AD}$ : a murine model with $H B E G F$ expression knocked out in cortex and hippocampus demonstrated the impaired psychiatric and cognitive functions expected with down-regulation of NMDA receptors ${ }^{76}$.

While our analyses benefitted from the combined statistical power of large, wellcharacterized AD GWAS collections with biobank GWAS data, we had several concerns about the different phenotype ( $\mathrm{AD} /$ dementia parental history) we used in the UKBB. Following up discovery-level associations first in EADB and then in UKBB, while we expected and observed reduced statistical significance in those data because of the "winner's curse," we noticed lower strength of association (ORs closer to 1) across variants in UKBB compared to IGAP and EADB, which had similar strength of association, although the directions of association and minor allele frequencies were similar for most variants across all three datasets/collections. We surmise that this may indicate the effect of two forms of "misclassification" in the AD/dementia parental history phenotype relative to LOAD affection status: (1) as subject ages-at-exam in UKBB are mostly below the LOAD average age-of-onset in IGAP and EADB, the parental history phenotype misclassifies true future AD status, as some persons with parental history will not develop AD and some persons without parental history will develop AD; (2) as the phenotype includes parental history of dementia, some subjects are likely at elevated risk of alternate causes of dementia (e.g., Parkinsonian dementia, Frontotemporal Dementia, and Lewy Body Disease, among others) relative to their risk for $\mathrm{AD}$. While we expect that (1) might explain reduced associations in UKBB, we performed a discovery GWAS analysis using UKBB and the parental history phenotype to determine whether a large set of non-AD loci would be identified. If this were the case, this would suggest that the more concerning form of misclassification might be (2). In comparing the top hits of the two analyses, a substantial overlap was observed among the strongest 
medRxiv preprint doi: https://doi.org/10.1101/2021.03.14.21253553; this version posted March 24, 2021. The copyright holder for this preprint (which was not certified by peer review) is the author/funder, who has granted medRxiv a license to display the preprint in perpetuity. It is made available under a CC-BY-NC-ND 4.0 International license .

IGAP HRC GWAS Meta-Analysis Naj et al.

associations, which included GWS associations in the $A P O E$ region, $B I N 1, H L A-D R B 1, A B C A 7$, PICALM, ADAM10, the $M S 4 A$ region, and CR1. Several of these top associations are shared across multiple neurodegenerative phenotypes (e.g., HLA-DRB1 in Parkinson's disease (PD)). One association with GWS after combining UKBB and IGAP was observed in $E P H X 2$, which has some prior evidence of association with $\mathrm{AD}^{77}$ and upregulation of its hydrolase activity leads to increased neuronal cell death ${ }^{78}$, though it is unclear if this association is capturing the effects of variation at the proximal genes $C L U$ and $P T K 2 B$. A discovery-level association (rs575683378, $\left.P=4.85 \times 10^{-6}\right)$ was observed for a rare variant $(\mathrm{MAF}=0.0014)$ in the gene encoding $\alpha$-synuclein $(S N C A)$, as established PD locus, however a similar rare variant association was not observed at or near this variant in IGAP. While this does not rule out possible misclassification effects from persons with higher risk of dementia from non-AD causes, it suggests that the higher prevalence of $\mathrm{AD}$ relative to other forms of dementia likely exerts minimal effect on the most strongly associated AD loci. It remains unclear if combining LOAD GWAS studies in IGAP and EADB with less rigorously defined case definitions like in UKBB would increase the possibility of misclassification. Therefore, the increased sample size available from the integration of studies with "silver standard" phenotypes (such as UKBB) may be useful if evaluated with appropriate caution regarding study conclusions ${ }^{79}$.

This study has several potential limitations, including modest increases in sample sizes from prior AD GWAS meta-analyses and potentially reduced power to detect novel AD loci by excluding the UKBB GWAS from discovery-level analyses. While the modest growth in sample size may have provided limited additional power to detect several additional novel common variant loci, we believe the strength of the analysis lie in the ability to robustly identify rare variant associations by combining high-quality rare variant imputation and a score-based regression 
medRxiv preprint doi: https://doi.org/10.1101/2021.03.14.21253553; this version posted March 24, 2021. The copyright holder for this preprint (which was not certified by peer review) is the author/funder, who has granted medRxiv a license to display the preprint in perpetuity. It is made available under a CC-BY-NC-ND 4.0 International license .

IGAP HRC GWAS Meta-Analysis Naj et al.

approach that stabilized measures of effect size and standard error estimates across individual studies. Without this strategy, it is unlikely that rare variant associations could have been examined in small datasets due to wide variability in effect betas and standard errors, which would not be distinguishable from other sources of heterogeneity between studies. Regarding the decision to not include UKBB in our IGAP discovery analyses, our secondary analysis of UKBB showed that while combining IGAP and UKBB may have identified additional AD GWAS loci, it may have also led to discovery-level significance $\left(P<10^{-5}\right)$ of risk variants for other dementia causes being potentially misreported as AD susceptibility loci if those loci have strong effects in UKBB alone. Those loci might yield valuable insights into AD pathogenesis, but would require additional scrutiny with pleiotropy analyses and functional genomics studies to confirm that their roles in neurodegeneration are important to AD.

\section{Methods}

Variant- and sample-level quality control (QC) on Stage 1 IGAP data. Standard QC was performed on individual IGAP datasets using PLINK v1.9 ${ }^{80-82}$ and including filtering and reestimating all quality metrics after excluding variants with a missingness rate of $>10 \%$ of genotype calls. QC filters included exclusions on SNPs with call rates below 98\% for Illumina and 95\% for Affymetrix panels; SNPs with departure from Hardy-Weinberg Equilibrium (HWE) of $P<10^{-6}$ among cognitively normal elders (CNEs, either non-cases or controls) for variants of MAF $>0.01$; and SNPs with informative missingness by case-CNE status of $P<10^{-6}$. Samples were dropped if the individual call rate was $<95 \%$; if $\mathrm{X}$ chromosome heterozygosity indicated inconsistency between predicted and reported sex; or if population substructure analyses (described below) indicated the sample did not cluster with 1000 Genomes Phase 3 populations of European ancestry. 
medRxiv preprint doi: https://doi.org/10.1101/2021.03.14.21253553; this version posted March 24, 2021. The copyright holder for this preprint (which was not certified by peer review) is the author/funder, who has granted medRxiv a license to display the preprint in perpetuity. It is made available under a CC-BY-NC-ND 4.0 International license .

IGAP HRC GWAS Meta-Analysis Naj et al.

More details including differences in QC approach for EADB and UKBB are provided in the Methods section of the Supplemental Note.

Relatedness Checks in Stage 1 IGAP data. Relatedness was assessed using the "--genome" function of PLINK v1.9. Using 20,000 linkage disequilibrium (LD)-pruned SNPs sampled from among genotyped variants, $\hat{\pi}$ (the proportion of alleles shared IBD) was estimated across all pairs of subjects across all ADGC datasets. Among pairs of subjects with no known familial relationships, one sample was excluded among pairs with $\hat{\pi}>0.95$ if phenotype and covariate data matched, otherwise both samples were excluded; among all pairs with $\hat{\pi}>0.4$ but less than 0.95 , one sample was kept giving preference to cases over CNEs, age (earlier age-at-onset among case pairs, later age-at-exam among CNE pairs). Pairs of relatives were dropped from family datasets if $\hat{\pi}$ differed substantially from expectation based on their reported relationships.

Population substructure in Stage 1 IGAP data. To identify samples of non-European ancestry, we performed a principal components (PCs) analysis using 'smartpca' in EIGENSOFT ${ }^{83,84}$ on the subset of $\sim 20,000$ LD-pruned SNPs used for relatedness checks on genotypes from all samples within each individual dataset and from the 1000 Genomes Phase III reference panels. Subjects not clustering with European ancestry groups were excluded from analysis. To account for the effects of population substructure in our analysis, a second PC analysis was performed using only the remaining subjects in each dataset. PCs 1-10 were examined for association with AD casecontrol status and eigenvector loading, and only PCs showing nominal association with AD $(P<0.05)$ and eigenvector loadings $>3$ were used in covariate adjustment for populations substructure, (average number of PCs used is 3; range: 2-4).

Imputation of Stage 1 IGAP data. For each dataset, SNPs not directly genotyped were imputed on the Michigan Imputation Server (MIS) ${ }^{85}$ using samples of all ancestries available on the 
medRxiv preprint doi: https://doi.org/10.1101/2021.03.14.21253553; this version posted March 24, 2021. The copyright holder for this preprint (which was not certified by peer review) is the author/funder, who has granted medRxiv a license to display the preprint in perpetuity. It is made available under a CC-BY-NC-ND 4.0 International license .

IGAP HRC GWAS Meta-Analysis Naj et al.

Haplotype Reference Consortium (HRC) 1.1 reference panel ${ }^{86}$, which includes 39,235,157 SNPs observed on 64,976 haplotypes (from 32,488 subjects), all with an estimated minor allele count (MAC) $\geq 5$ and observed in samples from at least two separately-ascertained data sources. Phasing on the MIS was done with EAGLE ${ }^{87}$ while imputation was performed using Minimac $3^{85}$. Quality of imputation for all variants was assessed using $R^{2}$ for imputation quality, although all variants were retained and not filtered prior to analysis. Following imputation and analysis, variants were filtered using two quality thresholds, a conservative $R^{2} \geq 0.8$, suggested to assure high quality of rare variants with $\mathrm{MAF} \leq 0.01$, and a more liberal $R^{2} \geq 0.3$ to evaluate common variants (MAF $\left.>0.01\right)$. Analysis of SNP imputation quality by bin of MAF revealed that more than $80 \%$ of variants of MAF $>0.0005$ had $R^{2} \geq 0.8$; among variants with $\mathrm{MAF} \leq 0.0005$, approximately $50 \%$ of variants had $R^{2} \geq 0.8$ in most datasets with $\mathrm{n}>1,000$ subjects. Final Stage 1 (IGAP) analyses include only variants of $R^{2} \geq 0.8$, using a global average of $R^{2}$ across all datasets weighted by sample size, to minimize potential bias from differences in imputation quality across datasets, while imputation quality were relaxed to $R^{2}>0.4$ for the same variants followed up in EADB and UKBB. Genotyped and imputed variants were all mapped to the mapped to the GRCh137/hg19 human genome build.

Single-variant Association Analysis and Meta-analysis for Common Variants (MAF>0.01). Single variant-based association analysis on datasets of unrelated cases and CNEs were performed in SNPTEST ${ }^{88}$ using score-based logistic regression under an additive model with minimal covariate adjustment for PCs and study-specific indicator variables only. Additional analyses with adjustment for age (defined as age-at-onset for cases and age-at-last exam for CNEs), sex, and dosages of $A P O E \varepsilon 4(0 / 1 / 2$ copies $)$ and $A P O E \varepsilon 2$ were evaluated and we observed similar findings to those reported for the minimally adjusted model, however those results are not shown. Familybased datasets were analyzed using the $\mathrm{GWAF}^{89}$ package in $\mathrm{R}^{90}$ which implemented a generalized 
medRxiv preprint doi: https://doi.org/10.1101/2021.03.14.21253553; this version posted March 24, 2021. The copyright holder for this preprint (which was not certified by peer review) is the author/funder, who has granted medRxiv a license to display the preprint in perpetuity. It is made available under a CC-BY-NC-ND 4.0 International license .

IGAP HRC GWAS Meta-Analysis Naj et al.

estimating equation (GEE) approach to account for correlation between subjects. After association analysis on imputed data, variants with regression coefficient of $|\beta|>5$, negative standard errors, or $P$-values equal to 0 or 1 were excluded from further analysis. Within-study association results for common variants (MAF>0.01) were meta-analyzed using a fixed-effects approach with inverse variance-weighting and with genomic control using METAL ${ }^{91}$.

Single-variant Association Analysis and Meta-analysis for Rare Variants (MAF $\leq 0.01)$. Rare variant association and meta-analysis was performed for individual variants using the SeqMeta ${ }^{92}$ package in $\mathrm{R}^{90}$. SeqMeta performs a score-based logistic regression, estimating scores in individuals using 'prepScores()' and performing meta-analysis using 'singleSNPMeta()'. Familybased datasets were analyzed by selecting a maximally informative subset of unrelated individuals for analysis, and no datasets with fewer than 100 cases and/or CNEs were analyzed (including the CSDC which demonstrated extreme association patterns and genomic inflation suggesting potential bias). As in common variant analyses, models evaluated included covariate adjustment for PCs. After meta-analysis of imputed rare variants, any SNPs with a regression coefficient of $|\beta|>5$, negative standard errors, or $P$-values equal to 0 or 1 were excluded from further analysis.

MAGMA Gene-based Association and Pathway Analyses. We performed gene-based analyses and multiple pathway analyses of the IGAP GWAS using common variants (MAF $>0.01)$ with MAGMA v1.08 ${ }^{93}$. For gene-based analysis, MAGMA uses GWAS summary statistics to perform a SNP-wise analysis within a gene using either (a) the mean association statistic across all SNPs in a gene, denoted by "mean" in Supplementary Tables 12-14 and 16 or (b) a combination of the mean statistic and that of the most significant single SNP, denoted by "multi". MAGMA uses a numerical integration procedure combined with simulation to produce an accurate $P$-value that corrects for LD structure between variants. 
medRxiv preprint doi: https://doi.org/10.1101/2021.03.14.21253553; this version posted March 24, 2021. The copyright holder for this preprint (which was not certified by peer review) is the author/funder, who has granted medRxiv a license to display the preprint in perpetuity. It is made available under a CC-BY-NC-ND 4.0 International license .

IGAP HRC GWAS Meta-Analysis Naj et al.

Pathway/gene-set analyses perform a joint test of association on multiple genes to determine strength of association with the phenotype of interest compared to the association of all other genes in the genome (a "competitive" analysis), correcting for LD between genes. The version of MAGMA used (v1.08) was recently updated to fix an elevated rate of false-positive associations observed in prior analyses ${ }^{94}$. Gene sets used in the analyses were from $\mathrm{GO}^{95,96}$, $\mathrm{KEGG}^{97,98}$, REACTOME ${ }^{99,100}$, BIOCARTA $^{101}$, and MGI ${ }^{102}$ pathways. Analyses examined 17,574 genes with 7,565,152 common variants (MAF>0.01), in two subsets of analyses: (a) using variants within the annotated 5' and 3' boundaries of the genes and (b) using a 35-kb upstream/10-kb downstream window around each gene to incorporate potential regulatory variants ${ }^{103}$. LD structure from MAGMA was determined using a combined ADGC reference panel using HRC imputation and genotype assignment (based on genotype probability from imputation exceeding 0.9) including data on 31,876 subjects and $8,299,079$ variants. GO pathway analysis was restricted to GO terms containing between 10 and 2000 genes. No size restrictions were placed on the other gene sets, since there were many fewer of them. This resulted in a total of 10,042 gene sets for analysis. Multiple testing correction for the number of gene sets tested was applied by calculating $Q$-values using the R package 'qvalue'104.

MAGMA Co-Expression Analysis. While pathway analyses examine gene sets defined by their shared role in known biological pathways, co-expression analyses examine gene sets (modules) defined by correlated expression patterns in the same or related tissues, on the grounds that such genes are likely to have similar biological functions. Here we analyzed co-expression data from multiple annotation sources to identify modules of co-expressed genes enriched for the current GWAS signals using an approach implemented in previous IGAP studies ${ }^{12,42}$. We collated a large set of co-expression modules derived from brain tissue from the following studies: BRAINEAC ${ }^{105}$, 
medRxiv preprint doi: https://doi.org/10.1101/2021.03.14.21253553; this version posted March 24, 2021. The copyright holder for this preprint (which was not certified by peer review) is the author/funder, who has granted medRxiv a license to display the preprint in perpetuity. It is made available under a CC-BY-NC-ND 4.0 International license .

IGAP HRC GWAS Meta-Analysis Naj et al.

the Common Mind Consortium ${ }^{106}$, Gandal et al. $(2018)^{107}$, Gibbs et al. (2010) $)^{108}$, Neueder \& Bates $(2014)^{109}$, ROSMAP $^{110}$, PsychENCODE ${ }^{111}$, and Zhang et al. (2013) $)^{112}$. Since immunity plays an important role in genetic susceptibility to $\mathrm{AD}$, we also used $\mathrm{WGCNA}^{113}$ to derive co-expression modules from the monocyte gene expression data of Fairfax et al. (2014) $)^{114}$. A complete description of the datasets, along with the number and size of modules, is given in Supplementary Table 19. These modules were used as gene sets for testing enrichment of association signals with MAGMA v1.08 ${ }^{93}$. To facilitate biological interpretation of modules showing statistically significant enrichment, annotations of the modules were performed using gProfiler ${ }^{115}$.

Gene-based Association Analysis of Rare Variants. We performed gene-based testing on rare variants $(\mathrm{MAF} \leq 0.01)$ using two approaches: (a) burden tests ${ }^{116,117}$; and (b) SKAT-O ${ }^{118}$, which optimally combines the features of the sequence kernel association test (SKAT) ${ }^{119}$ and burden tests. SKAT testing pre-specified beta distribution weighting of $\beta(1,25)$ ("Wu weights"). As we examined variants with frequencies as low as MAF 0.0008 in IGAP datasets of varying sample size, we used the meta-analytic framework of SeqMeta in R to perform gene-based testing across datasets to limit asymptotic effects on the estimation of betas and standard errors due to small cell sizes. Using subject-level scores in individuals previously estimated using 'prepScores()' for single variant analyses, we performed gene-based testing of $29,138,970$ variants assigned to 22,650 genes with RefSeq ${ }^{120}$ release 85 using the 'skatOmeta()' argument for SKAT-O testing and 'burdenMeta()' for burden testing. Pre-analysis filtering of variants excluded variants at two imputation quality thresholds, $R^{2}>0.3$ and $R^{2}>0.8$, with gene-based analysis performed in parallel on variant sets at both thresholds. Post-analysis filtering of gene-based results excluded genes with fewer than two variants of MAF $\leq 0.01$, leaving a final set of 21,198 genes in the $R^{2}>0.3$ analysis and 20,377 genes in the $R^{2}>0.8$ analysis. 
medRxiv preprint doi: https://doi.org/10.1101/2021.03.14.21253553; this version posted March 24, 2021. The copyright holder for this preprint (which was not certified by peer review) is the author/funder, who has granted medRxiv a license to display the preprint in perpetuity. It is made available under a CC-BY-NC-ND 4.0 International license .

IGAP HRC GWAS Meta-Analysis Naj et al.

Gene-based Association Analysis of Rare Variants Using Predicted Deleteriousness. We further extended gene-based testing in SeqMeta/R by filtering on predicted deleteriousness using the Combined Annotation-Dependent Depletion (CADD) ${ }^{121}$ method. CADD ${ }^{122}$ systematically integrates multiple functional annotation metrics into the " $C$-score" to indicate predicted deleteriousness. We downloaded CADD $C$-score annotations (Development release v1.6) from the CADD server at the University of Washington for all $\sim 39.2 \mathrm{M}$ variants imputed by HRC and mapped these annotations to variants accordingly. After removing all variants of MAF $>0.01$ and variants of MAF $\leq 0.01$ to which no $C$-scores mapped, we applied imputation filters of $R^{2}>0.3$ and $R^{2}>0.8$ as before to generate two sets of variants, and then further filtered these into sets of variants with $C \geq 5, C \geq 10$, and $C \geq 15$ prior to gene-based testing. We used $C \geq 15$ as the highest threshold following CADD recommendations ${ }^{123}$ as this includes $5 \%$ of variants genome-wide and is the median C-score for all possible non-synonymous variants and canonical splice site changes. Following filtering on MAF, $R^{2}$, and $C$-score, less than $25 \%$ of all genes in the $R^{2}>0.8 / C \geq 10$ and $R^{2}>0.8 / C \geq 15$ subsets had at least one variant, so the only subsets analyzed were $R^{2}>0.8 / C \geq 5$, $R^{2}>0.3 / C \geq 10, R^{2}>0.3 / C \geq 15$, and $R^{2}>0.8 / C \geq 5$.

Functional Genomics Follow-Up at Loci with GWS Associations. To explore potential functional effects at the newly associated variants identified in this analysis, we performed several follow-up analyses and functionality assessments on both individual variants and genes such as (1) chromatin interaction analyses using annotation in whole-body and brain-specific tissue and cell types; (2) chromatin accessibility analyses using chromosome conformation capture and ATAC-Seq methods; (3) expression pattern differences between brain/non-brain tissues and cell types from existing resources; (4) genetically-regulated expression patterns using inferred 
medRxiv preprint doi: https://doi.org/10.1101/2021.03.14.21253553; this version posted March 24, 2021. The copyright holder for this preprint (which was not certified by peer review) is the author/funder, who has granted medRxiv a license to display the preprint in perpetuity. It is made available under a CC-BY-NC-ND 4.0 International license .

IGAP HRC GWAS Meta-Analysis Naj et al.

expression patterns through PrediXcan; and (5) effects of variation on alternate splicing and on populations of microglia subtypes in postmortem AD and cognitively normal brains.

PrediXcan and MultiXcan Analysis. These comprised two different analyses, a basic PrediXcan $^{124}$ analysis examining individual tissues and a MultiXcan ${ }^{125}$ analysis aggregating expression across multiple tissue types. Tissue-specific genetic expression modules (GReX) in IGAP were imputed with publicly-available gene expression imputation models constructed in reference transcriptome datasets, including the whole blood model for $\mathrm{DGN}^{126}$, the dorsolateral prefrontal cortex (DLPFC) model from the CommonMind Consortium ${ }^{127,128}$, and another 49 tissues models from the Genotype-Tissue Expression (GTEx) project (version v8) ${ }^{129}$. DGN and DLPFC models were trained using an elastic net approach, and the other models from GTEx v8 used multivariate adaptive shrinkage. S-PrediXcan was then run with summary statistics of qualifying GWS associations $\left(R^{2}>0.3\right.$ and MAF $\left.>0.01\right)$ with all 51 tissue-specific models described above and S-MultiXcan with two cross-tissue models, one model looking across all 49 GTEx tissues (“cross-all”) and one model looking across 13 GTEx brain tissues (“cross-brain").

Gene-based Phenome-wide Association Study. To investigate phenotypes and traits with shared genetic components, we conducted a phenome-wide association study in the DNA biobank at Vanderbilt University (BioVU). BioVU has collected DNA samples from over 280,000 participants and linked genetic data for over 70,000 to their electronic health records. To identify gene-trait associations phenome-wide, we used PredixVU, a PrediXcan-based application which estimates genetically regulated expression based on each individual's genotype data using GTEx v8 models in a subset of 23,000 genotyped BioVU individuals of European ancestry. ICD-9 (International Classification of Disease, 9th Edition) codes from electronic health records were mapped to phenotype codes ("PheCodes"), defining cases and control for a set of diseases and 
medRxiv preprint doi: https://doi.org/10.1101/2021.03.14.21253553; this version posted March 24, 2021. The copyright holder for this preprint (which was not certified by peer review) is the author/funder, who has granted medRxiv a license to display the preprint in perpetuity. It is made available under a CC-BY-NC-ND 4.0 International license .

IGAP HRC GWAS Meta-Analysis Naj et al.

symptoms ${ }^{130,131}$; a total of 1,514 PheCodes were included. Then, association between imputed expression and PheCode was calculated.

All genes identified from single-variant and gene-based common and rare variant analyses were tested to characterize traits associated with their imputed expression in the electronic health records linked to BioVU samples. To identify traits with shared expression architecture, we first tallied significant $(P<0.05)$ PredixVU association results for each trait with the selected genes. To obtain the $P$-value for each phenotype, we created an empirical distribution for each trait by first identifying the subset of selected genes expressed in a given tissue and then randomly selecting the same number of genes and assessing the number of genes in the random set that were associated with each trait in PredixVU. The process was repeated 100,000 times to create a null distribution, and the empirical $P$-value was estimated based on this permutation procedure. We performed a Bonferroni correction for 1,514 PheCodes, making the significance level $P<3.3 \times 10^{-5}$ for determining selected gene enrichment in GReX-trait association.

Chromatin Interaction and Regulatory Variant Modeling Database Interrogation. To determine whether variants of interest may be involved in physical interactions with elements such as enhancers, insulators, or promoters, we applied HIPPIE2 ${ }^{48}$ to high-throughput chromosome conformation capture (Hi-C) data from six human cell lines (GM12878, IMR90, K562, HMEC, HUVEC, NHEK) with matched Encyclopedia of DNA Elements (ENCODE) project ${ }^{132,133}$ and Roadmap Epigenomics Project ${ }^{47}$ functional genomic data to infer physically-interacting regions (PIRs). We examined the chromosomal region $\pm 50 \mathrm{~kb}$ flanking the variant to identify a potential enhancer/promoter interaction pair. We also explored chromatin interactions using the highresolution $(1 \mathrm{~kb})$ haploid and diploid three-dimensional (3D) genome maps constructed by Rao 
medRxiv preprint doi: https://doi.org/10.1101/2021.03.14.21253553; this version posted March 24, 2021. The copyright holder for this preprint (which was not certified by peer review) is the author/funder, who has granted medRxiv a license to display the preprint in perpetuity. It is made available under a CC-BY-NC-ND 4.0 International license .

IGAP HRC GWAS Meta-Analysis Naj et al.

and colleagues ${ }^{134}$ using Hi-C to characterize chromatin 'loop anchors', stretches of sequence motifs that typically bind to the CTCF protein in a paired fashion at the ends of a chromatin loop.

To determine potential regulatory effects of variants of interest, we looked at enhancer mapping from ChromHMM ${ }^{135}$, which integrates epigenomic states measured through chromatin immunoprecipitation and sequencing (ChIP-Seq) of histone modifications to mark active enhancers ${ }^{136,137}$ using 127 tissues and cell types from ENCODE and Roadmap data.

Examining Chromatin Accessibility and Looping using high resolution promoter-focused Capture $C$ and $A T A C-S e q$. To examine chromatin looping and accessibility at the variants of interest, we queried our ATAC-Seq (Assay for Transposase-Accessible Chromatin using Sequencing) and high-resolution Capture $\mathrm{C}$ database comprising multiple cell types and conditions. Our Capture C library design utilizes custom Agilent SureSelect capture baits targeting both ends of DpnII restriction fragments (mean size $\sim 450 \mathrm{bp}$ ) encompassing promoters (including alternative promoters) of all human coding genes, noncoding RNA, antisense RNA, snRNA, miRNA, snoRNA, and lincRNA transcripts, totaling 36,691 RNA baited fragments. Protocols for ATAC-Seq and Capture C have been described previously ${ }^{138}$.

We also investigated putative active promoters-enhancer interactions in epigenomic data from multiple brain cell types from the Nott et al. (2019) ${ }^{49}$ study. This dataset comprises ATACSeq, H3K4me3 and H3K27ac for neurons, astrocytes, microglia and oligodendrocytes from human brain biopsies, as well as cell specific-enhancers and chromatin looping data (PLAC-Seq) from microglia, neurons and oligodendrocytes.

Candidate Gene Expression Patterns across Tissue Types. We queried two publicly available databases for expression information on genes of interest, BioGPS ${ }^{139}$ and Brain RNA$\mathrm{Seq}^{140}$. BioGPS ${ }^{45}$, an online portal which combines extensive gene annotation resources to provide 
medRxiv preprint doi: https://doi.org/10.1101/2021.03.14.21253553; this version posted March 24, 2021. The copyright holder for this preprint (which was not certified by peer review) is the author/funder, who has granted medRxiv a license to display the preprint in perpetuity. It is made available under a CC-BY-NC-ND 4.0 International license .

IGAP HRC GWAS Meta-Analysis Naj et al.

comprehensive information on genes of interest, includes expression data from a multitude of sources including multi-tissue reference expression patterns from the Gene Atlas data sets ${ }^{141}$, mouse brain expression in the Allen Brain Atlas ${ }^{142}$, multiple expression quantitative trait loci studies $^{143}$ among others. Brain RNA-Seq ${ }^{144,145}$ is an on-line a transcriptomics database with singlecell RNA-Seq data on multiple cell types including neurons, astrocytes, oligodendrocyte precursor cells, newly formed oligodendrocytes, myelinating oligodendrocytes, microglia, endothelial cells, and pericytes from mouse and human brains.

Examining effects of candidate variants on microglia subpopulations in postmortem brains. We examined the effects of variants of interest on levels of microglia subpopulations originally identified using single-nucleus RNA sequencing applied to postmortem human brains from individuals with varied neuropathology and varied APOE and TREM2 genotypes. This approach identified a subpopulation of CD163-positive microglia responsive to amyloid deposition that were significantly attenuated in individuals carrying $A P O E$ and TREM2 risk haplotypes/genotypes ${ }^{46}$. 
medRxiv preprint doi: https://doi.org/10.1101/2021.03.14.21253553; this version posted March 24, 2021. The copyright holder for this preprint (which was not certified by peer review) is the author/funder, who has granted medRxiv a license to display the preprint in perpetuity.

\section{It is made available under a CC-BY-NC-ND 4.0 International license .}

IGAP HRC GWAS Meta-Analysis Naj et al.

\section{Acknowledgements}

(Currently under revision)

\section{Author Contributions}

(Currently under revision)

\section{Competing Interests Statement}

(Currently under revision) 
Table 1. Strongest regional common variant (MAF $\geq 0.01$ ) association results in IGAP (Stage 1), their associations in EADB, and combined analysis of IGAP and EADB (Stage 2)

\begin{tabular}{|c|c|c|c|c|c|c|c|c|c|c|c|c|c|c|}
\hline \multirow[b]{2}{*}{ Variant RSID } & \multirow[b]{2}{*}{ Chr } & \multirow[b]{2}{*}{$\begin{array}{c}\text { Basepair } \\
\text { (hg19) }\end{array}$} & \multirow[b]{2}{*}{ Genomic Region } & \multirow[b]{2}{*}{ EFF } & \multirow[b]{2}{*}{ REF } & \multicolumn{3}{|c|}{ Stage 1: IGAP } & \multicolumn{3}{|c|}{ EADB } & \multicolumn{3}{|c|}{ Stage 2: IGAP + EADB Meta-Analysis } \\
\hline & & & & & & EAF & $\begin{array}{c}\mathrm{OR} \\
(95 \% \mathrm{CI}) \\
\end{array}$ & $P$ & EAF & $\begin{array}{c}\text { OR } \\
(95 \% \mathrm{CI}) \\
\end{array}$ & $P$ & EAF & $\begin{array}{c}\text { OR } \\
(95 \% \mathrm{CI}) \\
\end{array}$ & $P$ \\
\hline rs7259620 & 19 & 45407788 & APOE Region* & A & G & 0.4397 & $0.67(0.65,0.69)$ & $2.25 \mathrm{E}-199$ & 0.4197 & $0.64(0.62,0.66)$ & $1.20 \mathrm{E}-210$ & 0.4308 & $0.66(0.64,0.67)$ & $1.15 \mathrm{E}-401$ \\
\hline rs6733839 & 2 & 127892810 & $B I N 1^{*}$ & $\mathrm{~T}$ & $\mathrm{C}$ & 0.3836 & $1.18(1.15,1.21)$ & $2.36 \mathrm{E}-35$ & 0.3991 & $1.21(1.18,1.25)$ & $5.12 \mathrm{E}-40$ & 0.3906 & $1.19(1.17,1.22)$ & $3.06 \mathrm{E}-73$ \\
\hline rs7110631 & 11 & 85856187 & PICALM $^{*}$ & $\mathrm{C}$ & $\mathrm{G}$ & 0.318 & $0.88(0.86,0.90)$ & $1.42 \mathrm{E}-20$ & 0.3065 & $0.88(0.85,0.91)$ & $2.77 \mathrm{E}-16$ & 0.3130 & $0.88(0.86,0.90)$ & $3.33 \mathrm{E}-35$ \\
\hline rs1582763 & 11 & 60021948 & MS4A Region* & A & G & 0.383 & $0.89(0.87,0.92)$ & $3.63 \mathrm{E}-18$ & 0.3597 & $0.90(0.87,0.92)$ & $1.52 \mathrm{E}-13$ & 0.3729 & $0.89(0.88,0.91)$ & $4.08 \mathrm{E}-30$ \\
\hline rs 867230 & 8 & 27468503 & $C L U^{*}$ & $\mathrm{C}$ & A & 0.4052 & $0.89(0.87,0.92)$ & $1.34 \mathrm{E}-17$ & 0.3875 & $0.90(0.87,0.92)$ & $2.75 \mathrm{E}-13$ & 0.3973 & $0.90(0.88,0.91)$ & $3.23 \mathrm{E}-29$ \\
\hline rs11218343 & 11 & 121435587 & SORL1* & $\mathrm{C}$ & $\mathrm{T}$ & 0.0424 & $0.80(0.75,0.85)$ & $1.10 \mathrm{E}-11$ & 0.0391 & $0.86(0.80,0.92)$ & $4.53 \mathrm{E}-5$ & 0.0409 & $0.83(0.79,0.87)$ & $6.69 \mathrm{E}-15$ \\
\hline rs1385742 & 6 & 47595155 & $C D 2 A P^{*}$ & A & $\mathrm{T}$ & 0.3626 & $1.09(1.06,1.12)$ & $7.41 \mathrm{E}-11$ & 0.3577 & $1.06(1.03,1.10)$ & $7.27 \mathrm{E}-5$ & 0.3605 & $1.08(1.06,1.10)$ & $5.37 \mathrm{E}-14$ \\
\hline rs12151021 & 19 & 1050874 & $A B C A 7^{*}$ & A & $\mathrm{G}$ & 0.3289 & $1.10(1.07,1.13)$ & $7.46 \mathrm{E}-11$ & 0.3306 & $1.15(1.12,1.18)$ & $8.98 \mathrm{E}-20$ & 0.3297 & $1.12(1.10,1.14)$ & $5.24 \mathrm{E}-28$ \\
\hline rs7920721 & 10 & 11720308 & $\begin{array}{l}\text { USPGNL/ } \\
\text { ECHDC3* }\end{array}$ & G & A & 0.3837 & $1.09(1.06,1.11)$ & 4.59E-10 & 0.3908 & $1.07(1.03,1.10)$ & $1.90 \mathrm{E}-5$ & 0.3869 & $1.08(1.06,1.10)$ & 7.11E-14 \\
\hline rs9323877 & 14 & 92934269 & SLC24A4* & $\mathrm{G}$ & A & 0.2422 & $1.09(1.06,1.13)$ & $1.01 \mathrm{E}-9$ & 0.2531 & $1.07(1.04,1.11)$ & $1.70 \mathrm{E}-5$ & 0.2470 & $1.08(1.06,1.11)$ & $1.28 \mathrm{E}-13$ \\
\hline $\begin{array}{l}\mathrm{rs} 7928419 \\
\end{array}$ & 11 & 47392114 & SPI1* & $\mathrm{G}$ & A & 0.3399 & $0.92(0.90,0.95)$ & $1.74 \mathrm{E}-9$ & 0.3330 & $0.95(0.92,0.98)$ & 0.00143 & 0.3369 & $0.94(0.92,0.95)$ & $3.52 \mathrm{E}-11$ \\
\hline rs 2526377 & 17 & 56410041 & $\begin{array}{c}B Z R A P I-A S I \\
\text { (TSPOAPI-ASI) }\end{array}$ & G & A & 0.4479 & $0.93(0.90,0.95)$ & $5.90 \mathrm{E}-9$ & 0.4465 & $0.94(0.91,0.96)$ & $1.07 \mathrm{E}-5$ & 0.4473 & $0.93(0.91,0.95)$ & 3.87E-13 \\
\hline rs11168036 & 5 & 139707439 & $H B E G F$ & $\mathrm{~T}$ & $\mathrm{G}$ & 0.4915 & $1.07(1.05,1.10)$ & $1.95 \mathrm{E}-8$ & 0.4873 & $0.99(0.96,1.01)$ & 0.331 & 0.4996 & $0.95(0.94,0.97)$ & $8.96 \mathrm{E}-07$ \\
\hline rs73223431 & 8 & 27219987 & PTK2B* & $\mathrm{T}$ & $\mathrm{C}$ & 0.3596 & $1.08(1.05,1.10)$ & $2.31 \mathrm{E}-8$ & 0.3682 & $1.07(1.04,1.11)$ & $1.198 \mathrm{E}-6$ & 0.3634 & $1.08(1.06,1.10)$ & $1.44 \mathrm{E}-13$ \\
\hline rs114285994 & 16 & 19935763 & $I Q C K^{*}$ & A & G & 0.1406 & $0.90(0.87,0.94)$ & $3.53 \mathrm{E}-8$ & 0.1223 & $0.98(0.94,1.02)$ & 0.353 & 0.133 & $0.93(0.91,0.96)$ & $1.54 \mathrm{E}-6$ \\
\hline rs12539172 & 7 & 100091795 & NYAPI* & $\mathrm{T}$ & $\mathrm{C}$ & 0.3135 & $0.93(0.90,0.95)$ & $1.32 \mathrm{E}-7$ & 0.3100 & $0.92(0.89,0.95)$ & $5.243 \mathrm{E}-7$ & 0.312 & $0.93(0.91,0.95)$ & $3.594 \mathrm{E}-13$ \\
\hline rs3135348 & 6 & 32394098 & HLA-DRB1/5* & A & G & 0.4248 & $1.07(1.04,1.10)$ & $2.25 \mathrm{E}-7$ & $\mathrm{NA}$ & NA & NA & 0.4248 & $1.07(1.04,1.10)$ & $2.11 \mathrm{E}-7$ \\
\hline rs10753507 & 1 & 21152380 & EIF4G3 & $\mathrm{T}$ & A & 0.4038 & $0.93(0.91,0.96)$ & $2.72 \mathrm{E}-7$ & 0.4013 & $0.97(0.94,1.00)$ & 0.0229 & 0.4027 & $0.95(0.93,0.97)$ & $9.47 \mathrm{E}-8$ \\
\hline rs11735125 & 4 & 66237551 & EPHAS & G & $\mathrm{C}$ & 0.0225 & $1.24(1.14,1.34)$ & $3.68 \mathrm{E}-7$ & 0.0243 & $1.00(0.91,1.09)$ & 0.991 & 0.0233 & $1.12(1.06,1.19)$ & $1.51 \mathrm{E}-4$ \\
\hline rs17462136 & 20 & 54987216 & CASS4* & C & G & 0.0919 & $0.89(0.85,0.93)$ & $3.92 \mathrm{E}-7$ & 0.0800 & $0.83(0.78,0.87)$ & $1.15 \mathrm{E}-12$ & 0.0870 & $0.86(0.83,0.89)$ & $2.91 \mathrm{E}-17$ \\
\hline rs140016620 & 16 & 70713787 & MTSSIL/IL34 & G & A & 0.0653 & $1.14(1.08,1.19)$ & $9.31 \mathrm{E}-7$ & 0.0628 & $1.09(1.03,1.16)$ & 0.00345 & 0.0642 & $1.12(1.07,1.16)$ & $1.80 \mathrm{E}-8$ \\
\hline rs56402156 & 7 & 143103481 & EPHAI* & A & G & 0.2002 & $0.93(0.90,0.95)$ & $1.26 \mathrm{E}-6$ & 0.1838 & $0.92(0.89,0.96)$ & $9.71 \mathrm{E}-6$ & 0.1932 & $0.92(0.90,0.95)$ & $5.72 \mathrm{E}-11$ \\
\hline rs1001158 & 4 & 11038456 & $C L N K$ & $\mathrm{G}$ & A & 0.2825 & $1.07(1.04,1.10)$ & $2.03 \mathrm{E}-6$ & 0.2841 & $1.07(1.04,1.10)$ & $2.63 \mathrm{E}-5$ & 0.2832 & $1.07(1.05,1.09)$ & $2.24 \mathrm{E}-10$ \\
\hline rs10858815 & 12 & 89391846 & $\begin{array}{l}\text { LOC728084/ } \\
\text { LINC02458 }\end{array}$ & $\mathrm{C}$ & A & 0.0411 & $0.85(0.80,0.91)$ & $2.07 \mathrm{E}-6$ & 0.0424 & $0.99(0.92,1.06)$ & 0.766 & 0.0417 & $0.91(0.87,0.96)$ & $2.28 \mathrm{E}-4$ \\
\hline rs3896609 & 15 & 51057868 & SPPL2A* & A & $\mathrm{C}$ & 0.1855 & $0.92(0.89,0.95)$ & $2.11 \mathrm{E}-6$ & 0.1863 & $0.98(0.94,1.01)$ & 0.181 & 0.1859 & $0.95(0.92,0.97)$ & $1.02 \mathrm{E}-5$ \\
\hline rs72985631 & 2 & 232829502 & $\begin{array}{l}\text { DIS3L2/ } \\
\text { INPP5D* }\end{array}$ & A & G & 0.0242 & $0.82(0.76,0.89)$ & $3.01 \mathrm{E}-6$ & 0.0211 & $0.98(0.89,1.08)$ & 0.694 & 0.0229 & $0.88(0.83,0.94)$ & $1.34 \mathrm{E}-5$ \\
\hline rs12580654 & 12 & 52268547 & ANKRD33 & $\mathrm{C}$ & G & 0.1061 & $1.10(1.06,1.15)$ & $3.48 \mathrm{E}-6$ & 0.1034 & $1.02(0.98,1.07)$ & 0.352 & 0.1049 & $1.07(1.03,1.10)$ & $4.56 \mathrm{E}-5$ \\
\hline rs143867193 & 17 & 61503610 & TANC2/ACE* & $\mathrm{T}$ & $\mathrm{C}$ & 0.0163 & $1.27(1.15,1.40)$ & $3.56 \mathrm{E}-6$ & 0.0146 & $1.10(0.98,1.24)$ & 0.0923 & 0.0156 & $1.19(1.11,1.29)$ & $3.91 \mathrm{E}-6$ \\
\hline rs6966331 & 7 & 37883793 & $N M E 8^{*}$ & $\mathrm{~T}$ & $\mathrm{C}$ & 0.3523 & $0.94(0.92,0.97)$ & $6.09 \mathrm{E}-6$ & 0.3480 & $0.94(0.91,0.97)$ & $2.88 \mathrm{E}-5$ & 0.3504 & $0.94(0.92,0.96)$ & $7.14 \mathrm{E}-10$ \\
\hline rs11028038 & 11 & 24605495 & LUZP2 & $\mathrm{C}$ & $\mathrm{T}$ & 0.2165 & $1.07(1.04,1.10)$ & $7.29 \mathrm{E}-6$ & 0.2143 & $0.97(0.94,1.00)$ & 0.0828 & 0.2156 & $1.03(1.00,1.05)$ & 0.0270 \\
\hline rs11236918 & 11 & 76448286 & $\begin{array}{c}\text { GUCY2EP/ } \\
\text { TSKU }\end{array}$ & A & $\mathrm{C}$ & 0.1122 & $1.09(1.05,1.13)$ & $8.13 \mathrm{E}-6$ & 0.1150 & $1.01(0.96,1.05)$ & 0.78793 & 0.1134 & $1.05(1.02,1.09)$ & $3.97 \mathrm{E}-4$ \\
\hline rs9960448 & 18 & 57986377 & $M C 4 R$ & $\mathrm{~T}$ & G & 0.2904 & $0.94(0.91,0.97)$ & $8.24 \mathrm{E}-6$ & 0.2773 & $1.00(0.97,1.03)$ & 0.9519 & 0.2848 & $0.96(0.94,0.98)$ & $6.46 \mathrm{E}-4$ \\
\hline
\end{tabular}

Abbreviations: Chr, chromosome; EFF, Effect allele; REF, reference allele; EAF, effect allele frequency; OR, Odds ratio; CI, Confidence interval; $P$, P-value

Shaded box indicates genome-wide significance within analysis stage

* Loci with prior associations in IGAP [Lambert et al. (2013) or Kunkle et al. (2019)] 


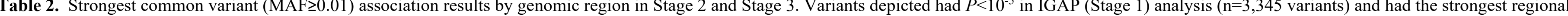
association in meta-analysis of IGAP+EADB (Stage 2). UKBB AD-proxy association results and meta-analysis of IGAP, EADB, and UKBB (Stage 3) are also shown.

\begin{tabular}{|c|c|c|c|c|c|c|c|c|c|c|c|c|c|c|}
\hline \multirow[b]{2}{*}{ Variant RSID } & \multirow[b]{2}{*}{ Chr } & \multirow[b]{2}{*}{$\begin{array}{c}\text { Basepair } \\
\text { (hg19) }\end{array}$} & \multirow[b]{2}{*}{ Genomic Region } & \multirow[b]{2}{*}{ EFF } & \multirow[b]{2}{*}{ REF } & \multicolumn{3}{|c|}{ Stage 2: IGAP + EADB Meta-Analysis } & \multicolumn{3}{|c|}{ UKB } & \multicolumn{3}{|c|}{ Stage 3: IGAP + EADB + UKB Meta-Analysis } \\
\hline & & & & & & EAF & $\begin{array}{c}\text { OR } \\
(95 \% \mathrm{CI})\end{array}$ & $P$ & EAF & $\begin{array}{c}\text { OR } \\
(95 \% \mathrm{CI})\end{array}$ & $\boldsymbol{P}$ & EAF & $\begin{array}{c}\text { OR } \\
(95 \% \text { CI })\end{array}$ & . \\
\hline rs112019714 & 19 & 45404857 & APOE Region* & $\mathrm{C}$ & $\mathrm{T}$ & 0.0384 & $2.51(2.39,2.63)$ & $2.25 \mathrm{E}-306$ & 0.0258 & $1.55(1.48,1.62)$ & $2.97 \mathrm{E}-86$ & 0.0332 & $1.92(1.86,1.99)$ & $1.78 \mathrm{E}-344$ \\
\hline rs6733839 & 2 & 127892810 & $B I N 1^{*}$ & $\mathrm{~T}$ & $\mathrm{C}$ & 0.3906 & $1.19(1.17,1.22)$ & $3.06 \mathrm{E}-73$ & 0.3893 & $1.07(1.05,1.09)$ & $1.97 \mathrm{E}-16$ & 0.3915 & $1.12(1.11,1.14)$ & $4.66 \mathrm{E}-73$ \\
\hline rs10792832 & 11 & 85867875 & PICALM $^{*}$ & A & $\mathrm{G}$ & 0.3621 & $0.88(0.87,0.90)$ & $6.48 \mathrm{E}-36$ & 0.3731 & $0.96(0.94,0.98)$ & $2.25 \mathrm{E}-6$ & 0.3675 & $0.93(0.91,0.94)$ & $6.04 \mathrm{E}-32$ \\
\hline rs679515 & 1 & 207750568 & $C R 1^{*}$ & $\mathrm{~T}$ & $\mathrm{C}$ & 0.2000 & $1.16(1.13,1.18)$ & $2.62 \mathrm{E}-34$ & 0.1754 & $1.05(1.03,1.07)$ & $2.59 \mathrm{E}-6$ & 0.1870 & $1.10(1.08,1.11)$ & $2.19 \mathrm{E}-31$ \\
\hline rs1582763 & 11 & 60021948 & MS4A Region* & A & $\mathrm{G}$ & 0.3729 & $0.89(0.88,0.91)$ & $4.08 \mathrm{E}-30$ & 0.3821 & $0.96(0.94,0.98)$ & $2.25 \mathrm{E}-6$ & 0.3773 & $0.93(0.92,0.94)$ & $2.66 \mathrm{E}-28$ \\
\hline rs867230 & 8 & 27468503 & $C L U^{*}$ & $\mathrm{C}$ & A & 0.3973 & $0.90(0.88,0.91)$ & $3.23 \mathrm{E}-29$ & 0.4135 & $0.96(0.95,0.98)$ & $9.38 \mathrm{E}-6$ & 0.4057 & $0.93(0.92,0.95)$ & $1.43 \mathrm{E}-26$ \\
\hline rs 3752246 & 19 & 1056492 & $A B C A 7^{*}$ & G & $\mathrm{C}$ & 0.1851 & $1.12(1.10,1.15)$ & $2.55 \mathrm{E}-20$ & 0.1762 & $1.02(0.99,1.04)$ & 0.166 & 0.1802 & $1.06(1.04,1.08)$ & $1.77 \mathrm{E}-12$ \\
\hline rs 17462136 & 20 & 54987216 & CASS4* & $\mathrm{C}$ & $\mathrm{G}$ & 0.0870 & $0.86(0.83,0.89)$ & $2.91 \mathrm{E}-17$ & 0.0875 & $0.96(0.94,0.99)$ & 0.0118 & 0.087 & $0.92(0.90,0.94)$ & $1.42 \mathrm{E}-13$ \\
\hline rs 9473123 & 6 & 47475339 & $C D 2 A P^{*}$ & A & G & 0.2699 & $1.08(1.06,1.11)$ & $3.55 \mathrm{E}-14$ & 0.2765 & $1.02(1.00,1.04)$ & 0.0154 & 0.2741 & $1.05(1.03,1.06)$ & $1.17 \mathrm{E}-11$ \\
\hline rs7912495 & 10 & 11718713 & $\begin{array}{l}\text { USP6NL/ } \\
\text { ECHDC3* }\end{array}$ & G & A & 0.4675 & $1.07(1.05,1.10)$ & $5.81 \mathrm{E}-14$ & 0.4533 & $1.03(1.01,1.05)$ & $3.07 \mathrm{E}-4$ & 0.4600 & $1.05(1.04,1.06)$ & $2.18 \mathrm{E}-14$ \\
\hline rs3993878 & 14 & 92931983 & SLC24A4* & G & A & 0.2562 & $1.09(1.06,1.11)$ & $7.80 \mathrm{E}-14$ & 0.2360 & $1.02(1.00,1.04)$ & 0.0391 & 0.2452 & $1.05(1.03,1.06)$ & $8.51 \mathrm{E}-11$ \\
\hline rs73223431 & 8 & 27219987 & PTK2B* & $\mathrm{T}$ & $\mathrm{C}$ & 0.3634 & $1.08(1.06,1.10)$ & 1.44E-13 & 0.3660 & $1.04(1.02,1.05)$ & $2.67 \mathrm{E}-5$ & 0.3657 & $1.05(1.04,1.07)$ & $1.12 \mathrm{E}-15$ \\
\hline rs117618017 & 15 & 63569902 & $A P H 1 B$ & $\mathrm{~T}$ & $\mathrm{C}$ & 0.1400 & $1.12(1.08,1.15)$ & $2.10 \mathrm{E}-13$ & 0.1393 & $1.04(1.02,1.06)$ & $8.79 \mathrm{E}-4$ & 0.1401 & $1.07(1.05,1.09)$ & $9.62 \mathrm{E}-13$ \\
\hline rs2526378 & 17 & 56404349 & $\begin{array}{c}\text { BZRAPI-ASI } \\
(T S P O A P I-A S I)\end{array}$ & G & A & 0.4526 & $0.93(0.91,0.95)$ & 2.31E-13 & 0.4487 & $0.99(0.97,1.00)$ & 0.158 & 0.4501 & $0.96(0.95,0.98)$ & $4.86 \mathrm{E}-9$ \\
\hline rs12539172 & 7 & 100091795 & NYAPI* & $\mathrm{T}$ & $\mathrm{C}$ & 0.3120 & $0.93(0.91,0.95)$ & $3.59 \mathrm{E}-13$ & 0.3264 & $0.96(0.94,0.97)$ & $2.41 \mathrm{E}-7$ & 0.3194 & $0.94(0.93,0.96)$ & $5.87 \mathrm{E}-18$ \\
\hline rs6586028 & 10 & 82253984 & TSPAN14 & $\mathrm{C}$ & $\mathrm{T}$ & 0.2017 & $0.92(0.90,0.94)$ & $2.33 \mathrm{E}-12$ & 0.2055 & $0.97(0.95,0.99)$ & 0.00215 & 0.2034 & $0.95(0.93,0.96)$ & $5.74 \mathrm{E}-12$ \\
\hline rs 2830500 & 21 & 28156856 & ADAMTSI* & A & $\mathrm{C}$ & 0.3123 & $0.93(0.91,0.95)$ & $3.41 \mathrm{E}-11$ & 0.2924 & $0.99(0.97,1.01)$ & 0.317 & 0.3009 & $0.97(0.95,0.98)$ & $2.97 \mathrm{E}-7$ \\
\hline rs75045569 & 7 & 143109208 & EPHA1* & G & $\mathrm{T}$ & 0.1625 & $0.92(0.89,0.94)$ & $4.47 \mathrm{E}-11$ & 0.1851 & $0.96(0.94,0.98)$ & $3.32 \mathrm{E}-5$ & 0.1753 & $0.94(0.93,0.96)$ & $1.43 \mathrm{E}-13$ \\
\hline rs 9275313 & 6 & 32665759 & HLA-DRB1/5* & $\mathrm{T}$ & $\mathrm{G}$ & 0.0983 & $0.90(0.87,0.93)$ & $5.37 \mathrm{E}-11$ & 0.1047 & $0.94(0.92,0.97)$ & $1.61 \mathrm{E}-5$ & 0.1016 & $0.92(0.91,0.94)$ & $5.48 \mathrm{E}-14$ \\
\hline rs 11039202 & 11 & 47382426 & SPII* & $\mathrm{T}$ & A & 0.3255 & $0.94(0.92,0.95)$ & $6.28 \mathrm{E}-11$ & 0.3227 & $1.00(0.98,1.01)$ & 0.5877 & 0.3238 & $0.97(0.96,0.98)$ & $2.59 \mathrm{E}-6$ \\
\hline rs2904297 & 4 & 11040290 & CLNK & $\mathrm{C}$ & $\mathrm{T}$ & 0.2846 & $1.07(1.05,1.09)$ & $1.20 \mathrm{E}-10$ & 0.2650 & $1.04(1.02,1.06)$ & $3.44 \mathrm{E}-5$ & 0.2742 & $1.05(1.04,1.07)$ & $1.92 \mathrm{E}-13$ \\
\hline rs 3781831 & 11 & 121436004 & SORL1* & A & G & 0.0223 & $0.81(0.76,0.86)$ & $1.66 \mathrm{E}-10$ & 0.0209 & $0.96(0.90,1.01)$ & 0.134 & 0.0215 & $0.89(0.85,0.93)$ & $7.75 \mathrm{E}-8$ \\
\hline rs9926151 & 16 & 19815411 & $I Q C K^{*}$ & $\mathrm{~A}$ & $\mathrm{G}$ & 0.1752 & $0.92(0.90,0.95)$ & $3.34 \mathrm{E}-10$ & 0.1725 & $1.00(0.98,1.02)$ & 0.878 & 0.1736 & $0.97(0.95,0.98)$ & $2.51 \mathrm{E}-5$ \\
\hline rs6966331 & 7 & 37883793 & $N M E 8^{*}$ & $\mathrm{~T}$ & $\mathrm{C}$ & 0.3504 & $0.94(0.92,0.96)$ & $7.14 \mathrm{E}-10$ & 0.3385 & $0.98(0.97,1.00)$ & 0.0645 & 0.3434 & $0.96(0.95,0.98)$ & $4.81 \mathrm{E}-8$ \\
\hline rs 34173062 & 8 & 145158607 & SHARPIN & A & $\mathrm{G}$ & 0.0857 & $1.13(1.09,1.18)$ & $1.56 \mathrm{E}-9$ & 0.0717 & $1.08(1.04,1.11)$ & $5.96 \mathrm{E}-6$ & 0.0777 & $1.10(1.07,1.13)$ & $2.67 \mathrm{E}-13$ \\
\hline rs11538963 & 16 & 70696272 & MTSSIL/IL34 & $\mathrm{C}$ & $\mathrm{T}$ & 0.0890 & $1.11(1.07,1.14)$ & $7.80 \mathrm{E}-9$ & -- & -- & -- & 0.0890 & $1.11(1.07,1.14)$ & $7.80 \mathrm{E}-9$ \\
\hline rs875121 & 19 & 50451508 & ATF5/SIGLEC11 & $\mathrm{C}$ & A & 0.2438 & $1.07(1.04,1.09)$ & $1.03 \mathrm{E}-8$ & 0.2475 & $1.03(1.01,1.05)$ & 0.00481 & 0.2464 & $1.04(1.03,1.06)$ & $4.84 \mathrm{E}-9$ \\
\hline rs185105129 & 17 & 61548353 & $A C E^{*}$ & $\mathrm{~T}$ & $\mathrm{C}$ & 0.0141 & $1.28(1.17,1.39)$ & $1.29 \mathrm{E}-8$ & 0.0166 & $1.12(1.05,1.19)$ & $2.58 \mathrm{E}-4$ & 0.016 & $1.17(1.12,1.23)$ & $2.96 \mathrm{E}-10$ \\
\hline rs114812713 & 6 & 41034000 & UNC5CL/OARDI* & $\mathrm{C}$ & $\mathrm{G}$ & 0.0236 & $1.20(1.12,1.27)$ & $1.85 \mathrm{E}-8$ & 0.0267 & $1.06(1.01,1.11)$ & 0.0274 & 0.0256 & $1.11(1.07,1.16)$ & $1.57 \mathrm{E}-7$ \\
\hline rs12407731 & 1 & 21254789 & EIF4G3 & $\mathrm{T}$ & $\mathrm{C}$ & 0.4476 & $0.95(0.94,0.97)$ & $4.72 \mathrm{E}-7$ & 0.4371 & $0.98(0.96,1.00)$ & 0.0148 & 0.4412 & $0.97(0.96,0.98)$ & $2.58 \mathrm{E}-7$ \\
\hline rs3131610 & 15 & 50800095 & USP50 & A & G & 0.2540 & $0.95(0.93,0.97)$ & $6.14 \mathrm{E}-7$ & 0.2502 & $0.97(0.96,0.99)$ & 0.00649 & 0.2514 & $0.96(0.95,0.98)$ & $9.73 \mathrm{E}-8$ \\
\hline rs7268 & 5 & 139712550 & HBEGF & $\mathrm{A}$ & $\mathrm{C}$ & 0.4530 & $1.05(1.03,1.07)$ & $9.33 \mathrm{E}-7$ & 0.4379 & $1.02(1.00,1.04)$ & 0.0244 & 0.4447 & $1.03(1.02,1.04)$ & $9.29 \mathrm{E}-7$ \\
\hline rs10411009 & 19 & 18606266 & $E L L$ & G & A & 0.3370 & $1.06(1.04,1.09)$ & $4.20 \mathrm{E}-6$ & 0.3519 & $1.00(0.99,1.02)$ & 0.769 & 0.3476 & $1.02(1.01,1.03)$ & 0.00595 \\
\hline rs62039712 & 16 & 79355857 & $W W O X^{*}$ & A & G & 0.1186 & $1.08(1.05,1.12)$ & $4.68 \mathrm{E}-6$ & 0.1215 & $1.01(0.99,1.04)$ & 0.391 & 0.1205 & $1.04(1.02,1.06)$ & $5.03 \mathrm{E}-4$ \\
\hline rs 12774458 & 10 & 7623127 & ITIH5 & G & A & 0.3654 & $0.95(0.93,0.97)$ & $7.53 \mathrm{E}-6$ & 0.3446 & $1.00(0.98,1.02)$ & 0.795 & 0.3525 & $0.98(0.97,1.00)$ & 0.0113 \\
\hline
\end{tabular}

Abbreviations: Chr, chromosome; EFF, Effect allele; REF, reference allele; $\mathrm{EAF}$, effect allele frequency; OR, Odds ratio; CI, Confidence interval; $P$, P-value

$$
\text { Shaded box indicates genome-wide significance within analysis stage }
$$

* Loci with prior associations in IGAP [Lambert et al. (2013) or Kunkle et al. (2019)] 
Table 3. All strongest rare variant (MAF $<0.01$ ) association results in IGAP (Stage 1) [no filtering on LD], their associations in EADB, and combined analysis of IGAP and EADB (Stage 2)

\begin{tabular}{|c|c|c|c|c|c|c|c|c|c|c|c|c|c|c|}
\hline \multirow[b]{2}{*}{ Variant RSID } & \multirow[b]{2}{*}{ Chr } & \multirow[b]{2}{*}{$\begin{array}{l}\text { Basepair } \\
\text { (hg19) }\end{array}$} & \multirow[b]{2}{*}{ Genomic Region } & \multirow[b]{2}{*}{ EFF } & \multirow[b]{2}{*}{ REF } & \multicolumn{3}{|c|}{ Stage 1: IGAP } & \multicolumn{3}{|c|}{ EADB } & \multicolumn{3}{|c|}{ Stage 2: IGAP + EADB Meta-Analysis } \\
\hline & & & & & & EAF & $\begin{array}{c}\text { OR } \\
(95 \% \mathrm{CI})\end{array}$ & $\boldsymbol{P}$ & EAF & $\begin{array}{c}\text { OR } \\
(95 \% \mathrm{CI})\end{array}$ & $\boldsymbol{P}$ & EAF & $\begin{array}{c}\text { OR } \\
(95 \% \mathrm{CI})\end{array}$ & $P$ \\
\hline rs547509922 & 19 & 45331261 & $\begin{array}{c}A P O E \text { Region } \\
\text { (intergenic) }\end{array}$ & $\mathrm{T}$ & $\mathrm{C}$ & 0.0048 & $2.80(2.31,3.40)$ & $1.12 \mathrm{E}-25$ & 0.0053 & $2.26(1.83,2.78)$ & $2.01 \mathrm{E}-15$ & 0.0051 & $2.54(2.2,2.92)$ & $5.04 \mathrm{E}-38$ \\
\hline rs559118614 & 19 & 45554058 & $\begin{array}{l}\text { APOE Region } \\
(C L A S R P)\end{array}$ & G & $\mathrm{T}$ & 0.0094 & $2.04(1.77,2.35)$ & $1.88 \mathrm{E}-22$ & 0.0097 & $2.42(2.06,2.84)$ & $5.64 \mathrm{E}-29$ & 0.0095 & $2.2(1.98,2.44)$ & $1.83 \mathrm{E}-47$ \\
\hline rs75932628 & 6 & 41129252 & TREM2 & $\mathrm{T}$ & $\mathrm{C}$ & 0.0043 & $2.45(1.99,3.02)$ & $3.72 \mathrm{E}-17$ & 0.0028 & $2.14(1.58,2.89)$ & $2.97 \mathrm{E}-07$ & 0.0038 & $2.34(1.97,2.78)$ & $2.15 \mathrm{E}-22$ \\
\hline rs187370608 & 6 & 40942196 & TREM2 (upstream) & A & $\mathrm{G}$ & 0.0042 & $2.19(1.78,2.70)$ & $2.34 \mathrm{E}-13$ & 0.0029 & $2.10(1.57,2.81)$ & $2.77 \mathrm{E}-07$ & 0.0038 & $2.16(1.82,2.56)$ & $8.70 \mathrm{E}-19$ \\
\hline rs143202663 & 6 & 40865240 & TREM2 (upstream) & $\mathrm{C}$ & $\mathrm{T}$ & 0.0040 & $2.11(1.71,2.61)$ & $2.59 \mathrm{E}-12$ & 0.0027 & $2.18(1.63,2.90)$ & $4.41 \mathrm{E}-08$ & 0.0036 & $2.14(1.80,2.53)$ & $1.83 \mathrm{E}-18$ \\
\hline rs 145342536 & 6 & 40911888 & TREM2 (upstream) & A & $\mathrm{T}$ & 0.0046 & $1.99(1.64,2.41)$ & $4.13 \mathrm{E}-12$ & 0.0029 & $2.07(1.56,2.75)$ & $2.14 \mathrm{E}-07$ & 0.0040 & $2.01(1.71,2.36)$ & $1.14 \mathrm{E}-17$ \\
\hline rs 12664332 & 6 & 40904030 & TREM2 (upstream) & A & $\mathrm{G}$ & 0.0045 & $1.95(1.61,2.37)$ & $1.57 \mathrm{E}-11$ & 0.0029 & $2.10(1.58,2.79)$ & $1.31 \mathrm{E}-07$ & 0.0040 & $2.00(1.70,2.34)$ & $2.98 \mathrm{E}-17$ \\
\hline rs112952132 & 19 & 45198060 & $\begin{array}{c}A P O E \text { Region } \\
\text { (intergenic) }\end{array}$ & $\mathrm{T}$ & $\mathrm{C}$ & 0.0084 & $0.60(0.52,0.70)$ & 7.41E-11 & 0.0085 & $0.74(0.63,0.87)$ & $2.93 \mathrm{E}-4$ & 0.0084 & $0.66(0.59,0.74)$ & $5.40 \mathrm{E}-13$ \\
\hline rs78905796 & 19 & 45132679 & $\begin{array}{l}\text { APOE Region } \\
\text { (IGSF23) }\end{array}$ & A & G & 0.0052 & $1.78(1.48,2.14)$ & $1.01 \mathrm{E}-9$ & 0.0049 & $1.79(1.44,2.23)$ & $1.47 \mathrm{E}-7$ & 0.005 & $1.78(1.55,2.05)$ & $1.13 \mathrm{E}-15$ \\
\hline rs540038005 & 15 & 61371352 & RORA & $\mathrm{T}$ & $\mathrm{C}$ & 0.00084 & $3.60(2.27,5.71)$ & $5.40 \mathrm{E}-8$ & 0.00087 & $0.80(0.49,1.31)$ & 0.370 & 0.0009 & $1.79(1.28,2.51)$ & $7.25 \mathrm{E}-4$ \\
\hline rs5551336410 & 15 & 61373788 & RORA & $\mathrm{T}$ & $\mathrm{C}$ & 0.00091 & $3.34(2.14,5.23)$ & $1.29 \mathrm{E}-7$ & 0.00090 & $0.77(0.47,1.26)$ & 0.297 & 0.0009 & $1.71(1.23,2.38)$ & 0.00141 \\
\hline $\mathrm{rs} 192675224$ & 6 & 706366 & TREM2 (upstream) & $\mathrm{A}$ & G & 0.0033 & $1.85(1.46,2.35)$ & $3.15 \mathrm{E}-7$ & 0.0023 & $1.70(1.26,2.29)$ & $4.65 \mathrm{E}-4$ & 0.0029 & $1.79(1.49,2.16)$ & $7.57 \mathrm{E}-10$ \\
\hline rs 150085726 & 6 & 40729544 & TREM2 (upstream) & $\mathrm{A}$ & $\mathrm{G}$ & 0.0033 & $1.86(1.47,2.37)$ & $3.24 \mathrm{E}-7$ & 0.0022 & $1.76(1.29,2.40)$ & $2.91 \mathrm{E}-4$ & 0.0029 & $1.82(1.51,2.20)$ & $4.84 \mathrm{E}-10$ \\
\hline rs143080277 & 2 & 106366056 & NCK2 & $\mathrm{C}$ & $\mathrm{T}$ & 0.0052 & $1.65(1.36,2.01)$ & $3.66 \mathrm{E}-7$ & 0.0056 & $1.32(1.08,1.61)$ & 0.00576 & 0.0054 & $1.48(1.29,1.70)$ & $2.69 \mathrm{E}-8$ \\
\hline rs17035636 & 3 & 36859000 & $\begin{array}{c}\text { LINC02033/TRANK1 } \\
\text { (downstream) }\end{array}$ & $\mathrm{C}$ & $\mathrm{T}$ & 0.0016 & $0.43(0.31,0.62)$ & $2.64 \mathrm{E}-6$ & 0.0026 & $0.85(0.62,1.16)$ & 0.302 & 0.0021 & $0.63(0.5,0.79)$ & $8.62 \mathrm{E}-5$ \\
\hline rs182464045 & 2 & 207595819 & $D Y T N / M D H 1 B$ & $\mathrm{~T}$ & $\mathrm{C}$ & 0.0013 & $2.40(1.66,3.47)$ & $3.14 \mathrm{E}-6$ & 0.0022 & $1.08(0.79,1.46)$ & 0.635 & 0.0018 & $1.49(1.18,1.89)$ & $8.55 \mathrm{E}-4$ \\
\hline rs78774825 & 8 & 81473635 & ZBTB10/ZNF704 & $\mathrm{T}$ & $\mathrm{G}$ & 0.0025 & $1.90(1.45,2.50)$ & $3.81 \mathrm{E}-6$ & 0.0035 & $0.97(0.74,1.27)$ & 0.831 & 0.003 & $1.36(1.12,1.65)$ & 0.00189 \\
\hline rs114999466 & 16 & 76230037 & $\begin{array}{l}\text { CNTNAP4 } \\
\text { (upstream) }\end{array}$ & G & A & 0.0069 & $0.69(0.59,0.81)$ & $3.91 \mathrm{E}-6$ & 0.0085 & $0.82(0.70,0.96)$ & 0.0114 & 0.0077 & $0.75(0.67,0.84)$ & $4.51 \mathrm{E}-7$ \\
\hline rs552075630 & 2 & 10693329 & ODC1/NOL10 & $\mathrm{T}$ & $\mathrm{G}$ & 0.0051 & $1.57(1.29,1.91)$ & $5.82 \mathrm{E}-6$ & 0.0051 & $1.07(0.86,1.33)$ & 0.525 & 0.0051 & $1.33(1.15,1.53)$ & $1.44 \mathrm{E}-4$ \\
\hline rs112120395 & 21 & 21159556 & LINC00320 & $\mathrm{G}$ & $\mathrm{T}$ & 0.0055 & $1.52(1.27,1.83)$ & $6.09 \mathrm{E}-6$ & 0.0054 & $0.90(0.74,1.09)$ & 0.267 & 0.0055 & $1.19(1.04,1.36)$ & 0.0107 \\
\hline rs527488596 & 3 & 90428380 & $\begin{array}{c}E P H A 3 \\
\text { (downstream) }\end{array}$ & A & $\mathrm{T}$ & 0.0055 & $0.65(0.53,0.78)$ & $6.32 \mathrm{E}-6$ & NA & (1) & NA & 0.0055 & $0.65(0.53,0.78)$ & $6.32 \mathrm{E}-6$ \\
\hline rs145472714 & 18 & 66411495 & $C C D C 102 B$ & G & $\mathrm{T}$ & 0.0077 & $0.70(0.60,0.82)$ & $9.24 \mathrm{E}-6$ & 0.0047 & $0.92(0.73,1.17)$ & 0.506 & 0.0068 & $0.76(0.67,0.87)$ & $5.46 \mathrm{E}-5$ \\
\hline
\end{tabular}

Abbreviation: Chr, chromosome; EFF, Effect allele; REF, reference allele; EAF, effect allele frequ

Shaded box indicates genome-wide significance within analysis stage 


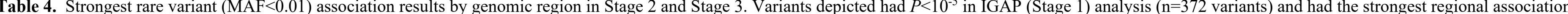

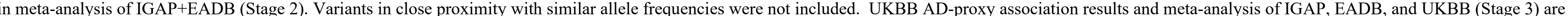
also shown.

\begin{tabular}{|c|c|c|c|c|c|c|c|c|c|c|c|c|c|c|}
\hline \multirow[b]{2}{*}{ Variant RSID } & \multirow[b]{2}{*}{ Chr } & \multirow{2}{*}{$\begin{array}{l}\text { Basepair } \\
\text { (hg19) }\end{array}$} & \multirow[b]{2}{*}{ Genomic Region } & \multirow[b]{2}{*}{ EFF } & \multirow[b]{2}{*}{ REF } & \multicolumn{3}{|c|}{ Stage 2: IGAP + EADB Meta-Analysis } & \multicolumn{3}{|c|}{ UKBB } & \multicolumn{3}{|c|}{ Stage 3: IGAP + EADB + UKBB Meta-Analysis } \\
\hline & & & & & & EAF & $\begin{array}{c}\text { OR } \\
(95 \% \mathrm{CI}) \\
\end{array}$ & $\boldsymbol{P}$ & EAF & $\begin{array}{c}\text { OR } \\
(95 \% \mathrm{CI})\end{array}$ & $P$ & EAF & $\begin{array}{c}\text { OR } \\
(95 \% \mathrm{CI}) \\
\end{array}$ & $\boldsymbol{P}$ \\
\hline rs183427010 & 19 & 45366498 & $\begin{array}{c}A P O E \text { Region } \\
(P V R L 2)\end{array}$ & A & G & 0.0093 & $2.81(2.51,3.13)$ & $5.32 \mathrm{E}-75$ & 0.0055 & $1.53(1.39,1.69)$ & $1.82 \mathrm{E}-17$ & 0.0075 & $2.00(1.86,2.15)$ & $1.53 \mathrm{E}-76$ \\
\hline rs75932628 & 6 & 41129252 & TREM2 & $\mathrm{T}$ & $\mathrm{C}$ & 0.0038 & $2.34(1.97,2.78)$ & $2.15 \mathrm{E}-22$ & 0.0025 & $1.45(1.25,1.69)$ & $9.00 \mathrm{E}-7$ & 0.0032 & $1.79(1.60,2.00)$ & $5.59 \mathrm{E}-24$ \\
\hline rs 143080277 & 2 & 106366056 & NCK2 & $\mathrm{C}$ & $\mathrm{T}$ & 0.0054 & $1.48(1.29,1.70)$ & $2.69 \mathrm{E}-08$ & 0.0041 & $1.34(1.18,1.52)$ & $3.22 \mathrm{E}-6$ & 0.0048 & $1.40(1.28,1.54)$ & $7.17 \mathrm{E}-13$ \\
\hline rs921719566 & 16 & 76230037 & $\begin{array}{l}\text { CNTNAP4 } \\
\text { (upstream) }\end{array}$ & G & A & 0.0077 & $0.75(0.67,0.84)$ & $4.51 \mathrm{E}-7$ & 0.0066 & $1.02(0.93,1.13)$ & 0.651 & 0.0071 & $0.89(0.83,0.96)$ & 0.00252 \\
\hline rs 1032524620 & 5 & 140854118 & $\begin{array}{c}P C D H G A / B \\
\text { (gene family cluster) }\end{array}$ & G & $\mathrm{C}$ & 0.0003 & $5.14(2.66,9.96)$ & $1.17 \mathrm{E}-6$ & -- & -- & -- & 0.0003 & $5.14(2.66,9.96)$ & $1.17 \mathrm{E}-6$ \\
\hline rs778473798 & 5 & 66025094 & MAST4 & $T$ & $\mathrm{G}$ & 0.0003 & $13.8(4.72,40.4)$ & $1.65 \mathrm{E}-6$ & -- & -- & -- & 0.0003 & $13.8(4.72,40.4)$ & $1.65 \mathrm{E}-6$ \\
\hline rs779452860 & 19 & 24444215 & $\begin{array}{c}\begin{array}{c}Z N F 254 \\
\text { (downstream) }\end{array} \\
\text { (d) }\end{array}$ & G & $\mathrm{T}$ & 0.0006 & $3.62(2.14,6.15)$ & $1.79 \mathrm{E}-6$ & -- & -- & -- & 0.0006 & $3.62(2.14,6.15)$ & $1.79 \mathrm{E}-6$ \\
\hline rs1004589836 & 18 & 59553737 & $R N F 152$ & $\mathrm{C}$ & $\mathrm{A}$ & 0.0004 & $3.93(2.20,7.02)$ & $3.81 \mathrm{E}-6$ & -- & -- & --- & 0.0004 & $3.93(2.20,7.02)$ & $3.81 \mathrm{E}-6$ \\
\hline rs570907469 & 2 & 158285821 & CYTIP & A & $\mathrm{G}$ & 0.0026 & $1.79(1.40,2.29)$ & $3.88 \mathrm{E}-6$ & 0.0025 & $1.04(0.88,1.22)$ & 0.677 & 0.0025 & $1.23(1.07,1.41)$ & 0.00338 \\
\hline rs 749016100 & 7 & 91966514 & $A N K I B 1$ & $\mathrm{G}$ & A & 0.0004 & $4.39(2.34,8.22)$ & $3.93 \mathrm{E}-6$ & -- & -- & -- & 0.0004 & $4.39(2.34,8.22)$ & $3.93 \mathrm{E}-6$ \\
\hline rs527488596 & 3 & 90428380 & $\begin{array}{c}\text { EPHA3 } \\
\text { (downstream) }\end{array}$ & A & $\mathrm{T}$ & 0.0055 & $0.65(0.53,0.78)$ & $6.32 \mathrm{E}-6$ & 0.0057 & $0.98(0.88,1.1)$ & 0.784 & 0.0056 & $0.88(0.80,0.97)$ & 0.0113 \\
\hline rs776752144 & 10 & 36231917 & $\begin{array}{c}\text { PCAT5 } \\
\text { (downstream) }\end{array}$ & G & $\mathrm{T}$ & 0.0002 & $13.1(4.28,40.0)$ & $6.43 \mathrm{E}-6$ & -- & -- & -- & 0.0002 & $13.1(4.28,40.0)$ & $6.43 \mathrm{E}-6$ \\
\hline rs958893222 & 3 & 104387013 & LCAM (upstream) & A & $\mathrm{G}$ & 0.0003 & $7.51(3.13,18.0)$ & $6.51 \mathrm{E}-6$ & -- & -- & -- & 0.0003 & $7.51(3.13,18.0)$ & $6.51 \mathrm{E}-6$ \\
\hline rs779246720 & 10 & 92032063 & HTR7 (downstream) & A & $\mathrm{G}$ & 0.0013 & $0.46(0.33,0.65)$ & $6.73 \mathrm{E}-6$ & -- & -- & -- & 0.0013 & $0.46(0.33,0.65)$ & $6.73 \mathrm{E}-6$ \\
\hline rs536943899 & 3 & 28624836 & $\begin{array}{c}Z C W P W 2 \\
\text { (downstream) }\end{array}$ & $\mathrm{C}$ & $\mathrm{T}$ & 0.0017 & $1.79(1.39,2.31)$ & $6.98 \mathrm{E}-6$ & 0.0025 & $1.00(0.85,1.19)$ & 0.955 & 0.0022 & $1.20(1.04,1.38)$ & 0.0109 \\
\hline rs190394847 & 21 & 45550148 & & A & $\mathrm{G}$ & 0.001 & $2.90(1.82,4.61)$ & $7.61 \mathrm{E}-6$ & 0.0012 & $0.90(0.70,1.17)$ & 0.440 & 0.0011 & $1.19(0.95,1.50)$ & 0.130 \\
\hline rs146698767 & 21 & 45 & PWP2 & A & $\mathrm{G}$ & 0.00 & $7,3.71)$ & $8.21 \mathrm{E}-6$ & & $0.91(0.72,1.14)$ & 0.397 & 0.0014 & $1.16(0.95,1.42)$ & 0.135 \\
\hline rs559275238 & 19 & & $E R C C 1$ & $\mathrm{G}$ & $\mathrm{T}$ & 0.0067 & $1.54(1.27,1.85)$ & $8.45 \mathrm{E}-6$ & 0.0080 & $1.06(0.96,1.16)$ & 0.263 & 0.0078 & $1.14(1.05,1.24)$ & 0.00282 \\
\hline rs138181035 & 19 & 44863163 & ZFP112 & $\mathrm{T}$ & $\mathrm{C}$ & 0.0037 & $0.67(0.57,0.80)$ & $8.60 \mathrm{E}-6$ & 0.0043 & $0.98(0.86,1.13)$ & 0.806 & 0.0041 & $0.85(0.76,0.95)$ & 0.00329 \\
\hline
\end{tabular}

Abbreviations: Chr, chromosome; EFF, Effect allele; REF, reference allele; EAF, effect allele frequency; OR, Odds ratio; CI, Confidence interval; $P$, P-value

Shaded box indicates genome-wide significance within analysis stage 


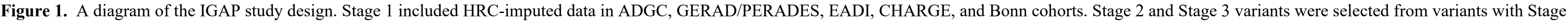

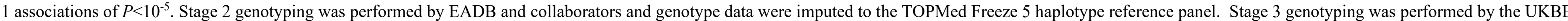

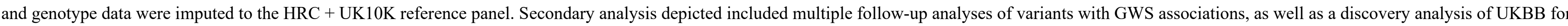
comparison against discovery-level associations in IGAP
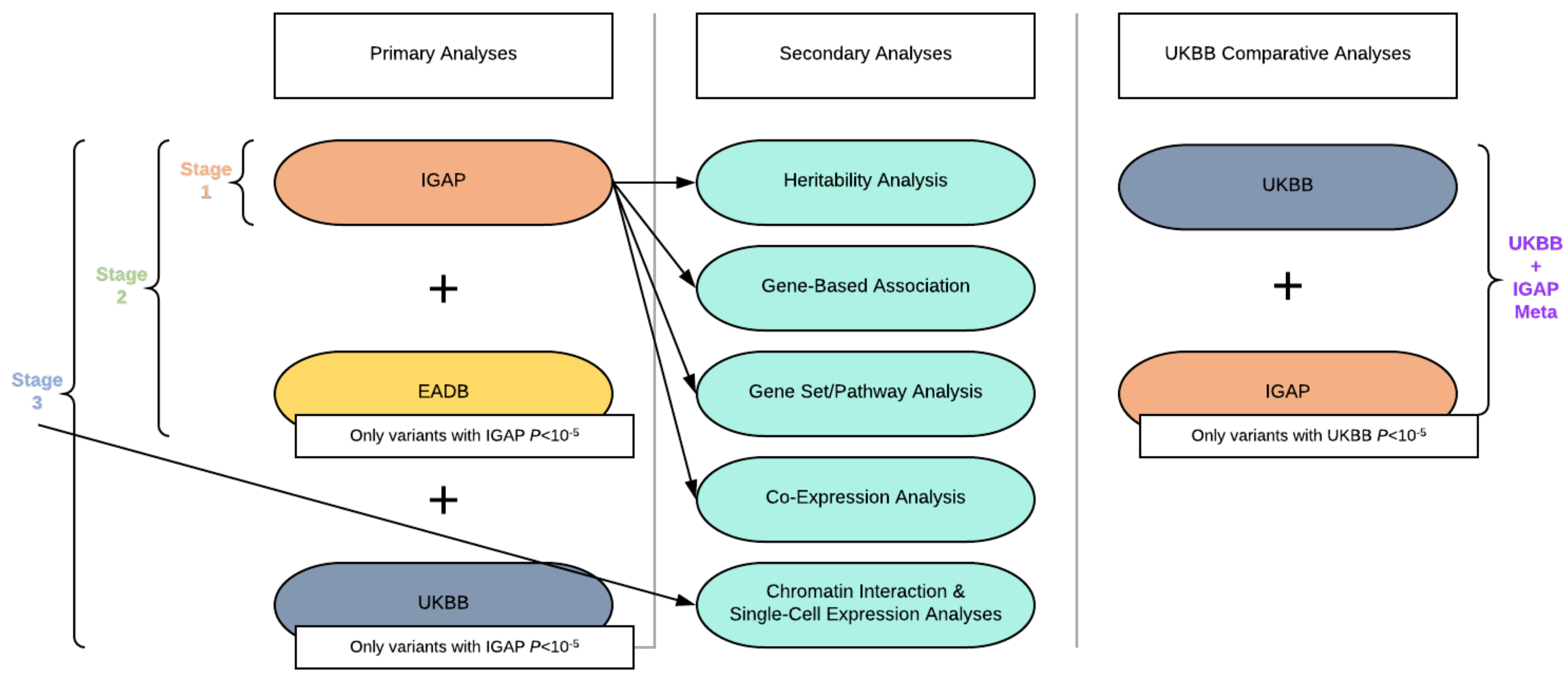


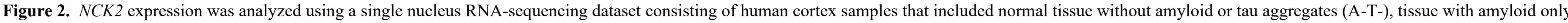

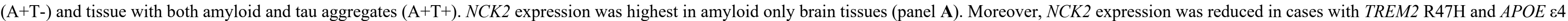

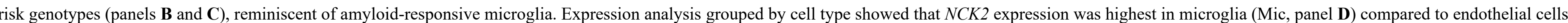

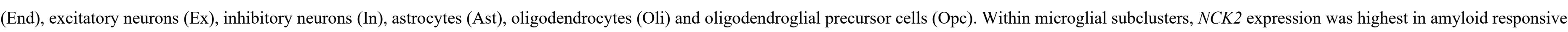
microglia (ARM, panel E)
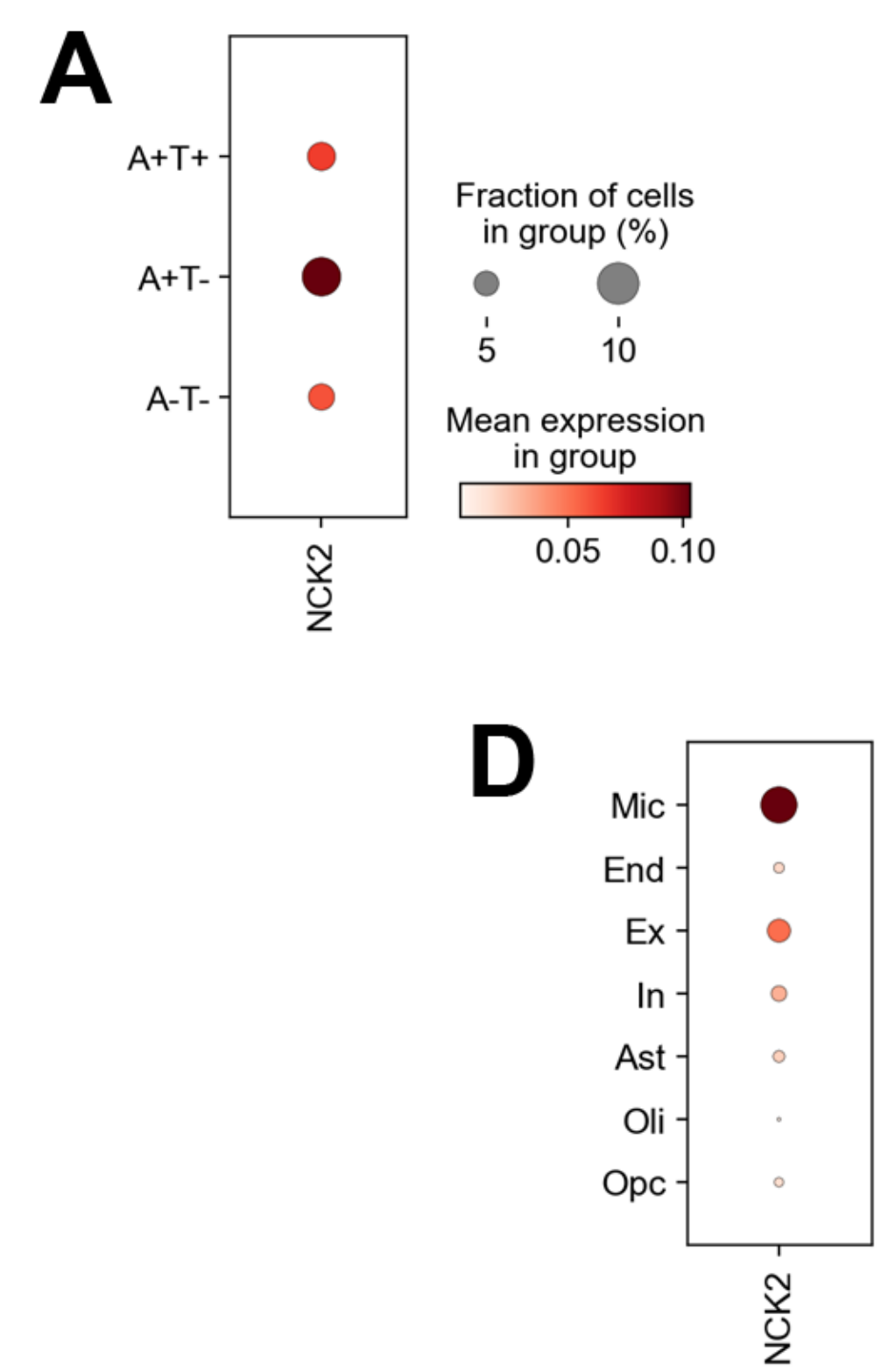

B

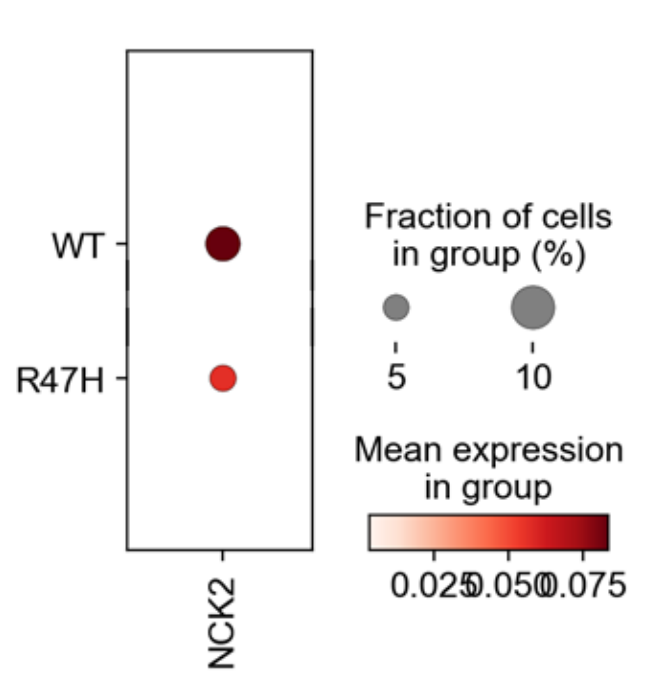

E

Fraction of cells in group (\%)

- 0 ००

51015202530

Mean expression in group

$\begin{array}{ll}0.1 & 0.2\end{array}$

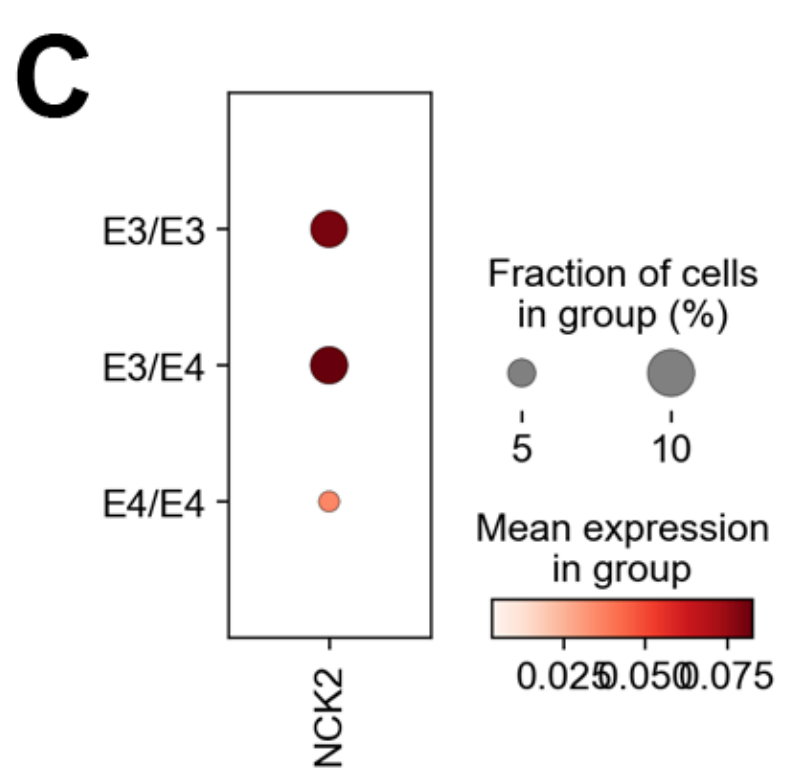

Fraction of cells in group (\%)

- 0 ०00

51015202530

Mean expression

in group

$0.0 \quad 0.5$ 
medRxiv preprint doi: https://doi.org/10.1101/2021.03.14.21253553; this version posted March 24, 2021. The copyright holder for this preprint (which was not certified by peer review) is the author/funder, who has granted medRxiv a license to display the preprint in perpetuity. It is made available under a CC-BY-NC-ND 4.0 International license .

IGAP HRC GWAS Meta-Analysis Naj et al.

\section{REFERENCES}

1. Gatz, M. et al. Role of genes and environments for explaining Alzheimer disease. Arch Gen Psychiatry 63, 168-74 (2006).

2. Escott-Price, V. et al. Common polygenic variation enhances risk prediction for Alzheimer's disease. Brain 138, 3673-84 (2015).

3. Harold, D. et al. Genome-wide association study identifies variants at CLU and PICALM associated with Alzheimer's disease. Nat Genet 41, 1088-93 (2009).

4. Lambert, J.C. et al. Genome-wide association study identifies variants at CLU and CR1 associated with Alzheimer's disease. Nat Genet 41, 1094-9 (2009).

5. Naj, A.C. et al. Common variants at MS4A4/MS4A6E, CD2AP, CD33 and EPHA1 are associated with late-onset Alzheimer's disease. Nat Genet 43, 436-41 (2011).

6. Seshadri, S. et al. Genome-wide analysis of genetic loci associated with Alzheimer disease. JAMA 303, 1832-40 (2010).

7. Hollingworth, P. et al. Common variants at ABCA7, MS4A6A/MS4A4E, EPHA1, CD33 and CD2AP are associated with Alzheimer's disease. Nat Genet 43, 429-35 (2011).

8. Lambert, J.C. et al. Meta-analysis of 74,046 individuals identifies 11 new susceptibility loci for Alzheimer's disease. Nat Genet 45, 1452-8 (2013).

9. Escott-Price, V. et al. Gene-wide analysis detects two new susceptibility genes for Alzheimer's disease. PLoS One 9, e94661 (2014).

10. Ruiz, A. et al. Follow-up of loci from the International Genomics of Alzheimer's Disease Project identifies TRIP4 as a novel susceptibility gene. Transl Psychiatry 4, e358 (2014).

11. Sims, R. et al. Rare coding variants in PLCG2, ABI3, and TREM2 implicate microglialmediated innate immunity in Alzheimer's disease. Nat Genet 49, 1373-1384 (2017).

12. Kunkle, B.W. et al. Genetic meta-analysis of diagnosed Alzheimer's disease identifies new risk loci and implicates Abeta, tau, immunity and lipid processing. Nat Genet 51, 414-430 (2019).

13. Jansen, I.E. et al. Genome-wide meta-analysis identifies new loci and functional pathways influencing Alzheimer's disease risk. Nat Genet 51, 404-413 (2019).

14. Zhang, X. et al. A rare missense variant of CASP7 is associated with familial late-onset Alzheimer's disease. Alzheimers Dement 15, 441-452 (2019).

15. Raghavan, N.S. et al. Whole-exome sequencing in 20,197 persons for rare variants in Alzheimer's disease. Ann Clin Transl Neurol 5, 832-842 (2018).

16. Patel, D. et al. Association of Rare Coding Mutations With Alzheimer Disease and Other Dementias Among Adults of European Ancestry. JAMA Netw Open 2, e191350 (2019).

17. Vardarajan, B.N. et al. Coding mutations in SORL1 and Alzheimer disease. Ann Neurol 77, 215-27 (2015).

18. Vardarajan, B.N. et al. Rare coding mutations identified by sequencing of Alzheimer disease genome-wide association studies loci. Ann Neurol 78, 487-98 (2015).

19. Steinberg, S. et al. Loss-of-function variants in ABCA7 confer risk of Alzheimer's disease. Nat Genet 47, 445-7 (2015).

20. Logue, M.W. et al. Two rare AKAP9 variants are associated with Alzheimer's disease in African Americans. Alzheimers Dement 10, 609-618 e11 (2014).

21. Jun, G. et al. PLXNA4 is associated with Alzheimer disease and modulates tau phosphorylation. Ann Neurol 76, 379-92 (2014).

22. Wetzel-Smith, M.K. et al. A rare mutation in UNC5C predisposes to late-onset Alzheimer's disease and increases neuronal cell death. Nat Med 20, 1452-7 (2014). 
medRxiv preprint doi: https://doi.org/10.1101/2021.03.14.21253553; this version posted March 24, 2021. The copyright holder for this preprint

(which was not certified by peer review) is the author/funder, who has granted medRxiv a license to display the preprint in perpetuity. It is made available under a CC-BY-NC-ND 4.0 International license .

IGAP HRC GWAS Meta-Analysis Naj et al.

23. Blue, E.E. et al. Genetic Variation in Genes Underlying Diverse Dementias May Explain a Small Proportion of Cases in the Alzheimer's Disease Sequencing Project. Dement Geriatr Cogn Disord 45, 1-17 (2018).

24. Tosto, G. \& Reitz, C. Genomics of Alzheimer's disease: Value of high-throughput genomic technologies to dissect its etiology. Mol Cell Probes 30, 397-403 (2016).

25. Naj, A.C., Schellenberg, G.D. \& Alzheimer's Disease Genetics, C. Genomic variants, genes, and pathways of Alzheimer's disease: An overview. Am J Med Genet B Neuropsychiatr Genet 174, 5-26 (2017).

26. Jonsson, T. et al. A mutation in APP protects against Alzheimer's disease and age-related cognitive decline. Nature 488, 96-9 (2012).

27. Jonsson, T. et al. Variant of TREM2 associated with the risk of Alzheimer's disease. $N$ Engl J Med 368, 107-16 (2013).

28. Guerreiro, R. et al. TREM2 variants in Alzheimer's disease. N Engl J Med 368, 117-27 (2013).

29. Pottier, C. et al. High frequency of potentially pathogenic SORL1 mutations in autosomal dominant early-onset Alzheimer disease. Mol Psychiatry 17, 875-9 (2012).

30. Logue, M.W. et al. Targeted Sequencing of Alzheimer Disease Genes in African Americans Implicates Novel Risk Variants. Front Neurosci 12, 592 (2018).

31. Bellenguez, C. et al. Contribution to Alzheimer's disease risk of rare variants in TREM2, SORL1, and ABCA7 in 1779 cases and 1273 controls. Neurobiol Aging 59, 220 e1-220 e9 (2017).

32. De Roeck, A. et al. An intronic VNTR affects splicing of ABCA7 and increases risk of Alzheimer's disease. Acta Neuropathol 135, 827-837 (2018).

33. Wu, Y., Zheng, Z., Visscher, P.M. \& Yang, J. Quantifying the mapping precision of genome-wide association studies using whole-genome sequencing data. Genome Biol 18, 86 (2017).

34. Panoutsopoulou, K., Tachmazidou, I. \& Zeggini, E. In search of low-frequency and rare variants affecting complex traits. Hum Mol Genet 22, R16-21 (2013).

35. Quick, C. et al. Sequencing and imputation in GWAS: Cost-effective strategies to increase power and genomic coverage across diverse populations. Genet Epidemiol 44, 537-549 (2020).

36. Surakka, I. et al. The impact of low-frequency and rare variants on lipid levels. Nat Genet 47, 589-97 (2015).

37. Bellenguez, C. et al. New insights on the genetic etiology of Alzheimer's and related dementia. medRxiv, 2020.10.01.20200659 (2020).

38. McDowell, I. Alzheimer's disease: insights from epidemiology. Aging (Milano) 13, 14362 (2001).

39. Jarvik, G., Larson, E.B., Goddard, K., Schellenberg, G.D. \& Wijsman, E.M. Influence of apolipoprotein E genotype on the transmission of Alzheimer disease in a communitybased sample. Am J Hum Genet 58, 191-200 (1996).

40. Slooter, A.J. et al. Risk estimates of dementia by apolipoprotein E genotypes from a population-based incidence study: the Rotterdam Study. Arch Neurol 55, 964-8 (1998).

41. Schwartzentruber, J. et al. Genome-wide meta-analysis, fine-mapping, and integrative prioritization identify new Alzheimer's disease risk genes. medRxiv, 2020.01.22.20018424 (2020). 
medRxiv preprint doi: https://doi.org/10.1101/2021.03.14.21253553; this version posted March 24, 2021. The copyright holder for this preprint

(which was not certified by peer review) is the author/funder, who has granted medRxiv a license to display the preprint in perpetuity. It is made available under a CC-BY-NC-ND 4.0 International license .

IGAP HRC GWAS Meta-Analysis Naj et al.

42. International Genomics of Alzheimer's Disease, C. Convergent genetic and expression data implicate immunity in Alzheimer's disease. Alzheimers Dement 11, 658-71 (2015).

43. Patel, H., Dobson, R.J.B. \& Newhouse, S.J. A Meta-Analysis of Alzheimer's Disease Brain Transcriptomic Data. J Alzheimers Dis 68, 1635-1656 (2019).

44. Beagan, J.A. \& Phillips-Cremins, J.E. On the existence and functionality of topologically associating domains. Nat Genet 52, 8-16 (2020).

45. Wu, C. et al. BioGPS: an extensible and customizable portal for querying and organizing gene annotation resources. Genome Biol 10, R130 (2009).

46. Nguyen, A.T. et al. APOE and TREM2 regulate amyloid-responsive microglia in Alzheimer's disease. Acta Neuropathol 140, 477-493 (2020).

47. Roadmap Epigenomics, C. et al. Integrative analysis of 111 reference human epigenomes. Nature 518, 317-30 (2015).

48. Kuksa, P.P. et al. HIPPIE2: a method for fine-scale identification of physically interacting chromatin regions. NAR Genom Bioinform 2, lqaa022 (2020).

49. Nott, A. et al. Brain cell type-specific enhancer-promoter interactome maps and diseaserisk association. Science 366, 1134-1139 (2019).

50. Su, C. et al. Mapping effector genes at lupus GWAS loci using promoter Capture-C in follicular helper T cells. Nat Commun 11, 3294 (2020).

51. Lasconi, C. et al. Variant-to-Gene-Mapping Analyses Reveal a Role for the Hypothalamus in Genetic Susceptibility to Inflammatory Bowel Disease. Cell Mol Gastroenterol Hepatol (2020).

52. Jun, G.R. et al. Transethnic genome-wide scan identifies novel Alzheimer's disease loci. Alzheimers Dement 13, 727-738 (2017).

53. Seipold, L. \& Saftig, P. The Emerging Role of Tetraspanins in the Proteolytic Processing of the Amyloid Precursor Protein. Front Mol Neurosci 9, 149 (2016).

54. Jouannet, S. et al. TspanC8 tetraspanins differentially regulate the cleavage of ADAM10 substrates, Notch activation and ADAM10 membrane compartmentalization. Cell Mol Life Sci 73, 1895-915 (2016).

55. Yuan, X.Z., Sun, S., Tan, C.C., Yu, J.T. \& Tan, L. The Role of ADAM10 in Alzheimer's Disease. J Alzheimers Dis 58, 303-322 (2017).

56. Krishnan, D., Menon, R.N., Mathuranath, P.S. \& Gopala, S. A novel role for SHARPIN in amyloid-beta phagocytosis and inflammation by peripheral blood-derived macrophages in Alzheimer's disease. Neurobiol Aging 93, 131-141 (2020).

57. Asanomi, Y. et al. A rare functional variant of SHARPIN attenuates the inflammatory response and associates with increased risk of late-onset Alzheimer's disease. Mol Med 25, 20 (2019).

58. Angelastro, J.M. et al. Regulated expression of ATF5 is required for the progression of neural progenitor cells to neurons. J Neurosci 23, 4590-600 (2003).

59. Angata, T. et al. Cloning and characterization of human Siglec-11. A recently evolved signaling molecule that can interact with SHP-1 and SHP-2 and is expressed by tissue macrophages, including brain microglia. J Biol Chem 277, 24466-74 (2002).

60. Wang, Y. \& Neumann, H. Alleviation of neurotoxicity by microglial human Siglec-11. $J$ Neurosci 30, 3482-8 (2010).

61. Serneels, L. et al. Differential contribution of the three Aph1 genes to gamma-secretase activity in vivo. Proc Natl Acad Sci US A 102, 1719-24 (2005). 
medRxiv preprint doi: https://doi.org/10.1101/2021.03.14.21253553; this version posted March 24, 2021. The copyright holder for this preprint

(which was not certified by peer review) is the author/funder, who has granted medRxiv a license to display the preprint in perpetuity. It is made available under a CC-BY-NC-ND 4.0 International license .

IGAP HRC GWAS Meta-Analysis Naj et al.

62. Biundo, F., Ishiwari, K., Del Prete, D. \& D'Adamio, L. Deletion of the gamma-secretase subunits Aph1B/C impairs memory and worsens the deficits of knock-in mice modeling the Alzheimer-like familial Danish dementia. Oncotarget 7, 11923-44 (2016).

63. Fagerberg, L. et al. Analysis of the human tissue-specific expression by genome-wide integration of transcriptomics and antibody-based proteomics. Mol Cell Proteomics 13, 397-406 (2014).

64. Alazami, A.M. et al. Accelerating novel candidate gene discovery in neurogenetic disorders via whole-exome sequencing of prescreened multiplex consanguineous families. Cell Rep 10, 148-61 (2015).

65. Michelson, D.J. et al. Evidence report: Genetic and metabolic testing on children with global developmental delay: report of the Quality Standards Subcommittee of the American Academy of Neurology and the Practice Committee of the Child Neurology Society. Neurology 77, 1629-35 (2011).

66. Lee, J.J. et al. Gene discovery and polygenic prediction from a genome-wide association study of educational attainment in 1.1 million individuals. Nat Genet 50, 1112-1121 (2018).

67. Zuroff, L.R. et al. Effects of IL-34 on Macrophage Immunological Profile in Response to Alzheimer's-Related Abeta42 Assemblies. Front Immunol 11, 1449 (2020).

68. Mizuno, T. et al. Interleukin-34 selectively enhances the neuroprotective effects of microglia to attenuate oligomeric amyloid-beta neurotoxicity. Am J Pathol 179, 2016-27 (2011).

69. Goitsuka, R. et al. A BASH/SLP-76-related adaptor protein MIST/Clnk involved in IgE receptor-mediated mast cell degranulation. Int Immunol 12, 573-80 (2000).

70. Lehman, H.K. Autoimmunity and Immune Dysregulation in Primary Immune Deficiency Disorders. Curr Allergy Asthma Rep 15, 53 (2015).

71. Cartier, L., Hartley, O., Dubois-Dauphin, M. \& Krause, K.H. Chemokine receptors in the central nervous system: role in brain inflammation and neurodegenerative diseases. Brain Res Brain Res Rev 48, 16-42 (2005).

72. Versijpt, J.J. et al. Assessment of neuroinflammation and microglial activation in Alzheimer's disease with radiolabelled PK11195 and single photon emission computed tomography. A pilot study. Eur Neurol 50, 39-47 (2003).

73. Galiegue, S. et al. Cloning and characterization of PRAX-1. A new protein that specifically interacts with the peripheral benzodiazepine receptor. $J$ Biol Chem 274, 2938-52 (1999).

74. Shash, D. et al. Benzodiazepine, psychotropic medication, and dementia: A populationbased cohort study. Alzheimers Dement 12, 604-13 (2016).

75. Nanba, D. \& Higashiyama, S. Dual intracellular signaling by proteolytic cleavage of membrane-anchored heparin-binding EGF-like growth factor. Cytokine Growth Factor Rev 15, 13-9 (2004).

76. Sasaki, K., Omotuyi, O.I., Ueda, M., Shinohara, K. \& Ueda, H. NMDA receptor agonists reverse impaired psychomotor and cognitive functions associated with hippocampal Hbegf-deficiency in mice. Mol Brain 8, 83 (2015).

77. Chapuis, J. et al. Genome-wide, high-content siRNA screening identifies the Alzheimer's genetic risk factor FERMT2 as a major modulator of APP metabolism. Acta Neuropathol 133, 955-966 (2017). 
medRxiv preprint doi: https://doi.org/10.1101/2021.03.14.21253553; this version posted March 24, 2021. The copyright holder for this preprint (which was not certified by peer review) is the author/funder, who has granted medRxiv a license to display the preprint in perpetuity. It is made available under a CC-BY-NC-ND 4.0 International license .

IGAP HRC GWAS Meta-Analysis Naj et al.

78. Koerner, I.P. et al. Polymorphisms in the human soluble epoxide hydrolase gene EPHX2 linked to neuronal survival after ischemic injury. $J$ Neurosci 27, 4642-9 (2007).

79. Huffman, J.E. Examining the current standards for genetic discovery and replication in the era of mega-biobanks. Nat Commun 9, 5054 (2018).

80. Purcell, S. et al. PLINK: a tool set for whole-genome association and population-based linkage analyses. Am J Hum Genet 81, 559-75 (2007).

81. Chang, C.C. et al. Second-generation PLINK: rising to the challenge of larger and richer datasets. Gigascience 4, 7 (2015).

82. Chang, C.C. Data Management and Summary Statistics with PLINK. Methods Mol Biol 2090, 49-65 (2020).

83. Price, A.L. et al. Principal components analysis corrects for stratification in genome-wide association studies. Nat Genet 38, 904-9 (2006).

84. Patterson, N., Price, A.L. \& Reich, D. Population structure and eigenanalysis. PLoS Genet 2, e190 (2006).

85. Das, S. et al. Next-generation genotype imputation service and methods. Nat Genet $\mathbf{4 8}$, 1284-1287 (2016).

86. McCarthy, S. et al. A reference panel of 64,976 haplotypes for genotype imputation. Nat Genet 48, 1279-83 (2016).

87. Loh, P.R. et al. Reference-based phasing using the Haplotype Reference Consortium panel. Nat Genet 48, 1443-1448 (2016).

88. Marchini, J., Howie, B., Myers, S., McVean, G. \& Donnelly, P. A new multipoint method for genome-wide association studies by imputation of genotypes. Nat Genet 39, 906-13 (2007).

89. Chen, M.H. \& Yang, Q. GWAF: an R package for genome-wide association analyses with family data. Bioinformatics 26, 580-1 (2010).

90. Team., R.D.C. R: a language and environment for statistical computing.

91. Willer, C.J., Li, Y. \& Abecasis, G.R. METAL: fast and efficient meta-analysis of genomewide association scans. Bioinformatics 26, 2190-1 (2010).

92. Voorman, A., Brody, J., Chen, H., Lumley, T. \& Davis, B. seqMeta: an R package for meta-analyzing region-based tests of rare DNA variants. (2013).

93. de Leeuw, C.A., Mooij, J.M., Heskes, T. \& Posthuma, D. MAGMA: generalized gene-set analysis of GWAS data. PLoS Comput Biol 11, e1004219 (2015).

94. Yurko, R., Roeder, K., Devlin, B. \& G'Sell, M. H-MAGMA, inheriting a shaky statistical foundation, yields excess false positives. bioRxiv, 2020.08.20.260224 (2020).

95. Ashburner, M. et al. Gene ontology: tool for the unification of biology. The Gene Ontology Consortium. Nat Genet 25, 25-9 (2000).

96. Gene Ontology, C. Gene Ontology Consortium: going forward. Nucleic Acids Res 43, D1049-56 (2015).

97. Kanehisa, M., Sato, Y., Kawashima, M., Furumichi, M. \& Tanabe, M. KEGG as a reference resource for gene and protein annotation. Nucleic Acids Res 44, D457-62 (2016).

98. Ogata, H. et al. KEGG: Kyoto Encyclopedia of Genes and Genomes. Nucleic Acids Res 27, 29-34 (1999).

99. Fabregat, A. et al. The Reactome pathway Knowledgebase. Nucleic Acids Res 44, D4817 (2016). 
medRxiv preprint doi: https://doi.org/10.1101/2021.03.14.21253553; this version posted March 24, 2021. The copyright holder for this preprint

(which was not certified by peer review) is the author/funder, who has granted medRxiv a license to display the preprint in perpetuity.

It is made available under a CC-BY-NC-ND 4.0 International license .

IGAP HRC GWAS Meta-Analysis

Naj et al.

100. Croft, D. et al. Reactome: a database of reactions, pathways and biological processes.

Nucleic Acids Res 39, D691-7 (2011).

101. Nishimura, D. BioCarta. Biotech Software and Internet Report 2, 117-120 (2001).

102. Eppig, J.T. et al. The Mouse Genome Database (MGD): facilitating mouse as a model for human biology and disease. Nucleic Acids Res 43, D726-36 (2015).

103. Pathway Analysis Subgroup of Psychiatric Genomics Consortium. Psychiatric genomewide association study analyses implicate neuronal, immune and histone pathways. Nat Neurosci 18, 199-209 (2015).

104. Storey, J.D., Bass, A.J., Dabney, A. \& Robinson, D. qvalue: Q-value estimation for false discovery rate control. R package version 2.22.0 edn (2020).

105. Ramasamy, A. et al. Genetic variability in the regulation of gene expression in ten regions of the human brain. Nat Neurosci 17, 1418-1428 (2014).

106. Fromer, M. et al. Gene expression elucidates functional impact of polygenic risk for schizophrenia. Nat Neurosci 19, 1442-1453 (2016).

107. Gandal, M.J. et al. Shared molecular neuropathology across major psychiatric disorders parallels polygenic overlap. Science 359, 693-697 (2018).

108. Gibbs, J.R. et al. Abundant quantitative trait loci exist for DNA methylation and gene expression in human brain. PLoS Genet 6, e1000952 (2010).

109. Neueder, A. \& Bates, G.P. A common gene expression signature in Huntington's disease patient brain regions. BMC Med Genomics 7, 60 (2014).

110. Mostafavi, S. et al. A molecular network of the aging human brain provides insights into the pathology and cognitive decline of Alzheimer's disease. Nat Neurosci 21, 811-819 (2018).

111. Gandal, M.J. et al. Transcriptome-wide isoform-level dysregulation in ASD, schizophrenia, and bipolar disorder. Science 362(2018).

112. Zhang, B. et al. Integrated systems approach identifies genetic nodes and networks in late-onset Alzheimer's disease. Cell 153, 707-20 (2013).

113. Langfelder, P. \& Horvath, S. WGCNA: an R package for weighted correlation network analysis. BMC Bioinformatics 9, 559 (2008).

114. Fairfax, B.P. et al. Innate immune activity conditions the effect of regulatory variants upon monocyte gene expression. Science 343, 1246949 (2014).

115. Raudvere, U. et al. g:Profiler: a web server for functional enrichment analysis and conversions of gene lists (2019 update). Nucleic Acids Res 47, W191-W198 (2019).

116. Madsen, B.E. \& Browning, S.R. A groupwise association test for rare mutations using a weighted sum statistic. PLoS Genet 5, e1000384 (2009).

117. Han, F. \& Pan, W. A data-adaptive sum test for disease association with multiple common or rare variants. Hum Hered 70, 42-54 (2010).

118. Lee, S. et al. Optimal unified approach for rare-variant association testing with application to small-sample case-control whole-exome sequencing studies. Am J Hum Genet 91, 224-37 (2012).

119. Wu, M.C. et al. Rare-variant association testing for sequencing data with the sequence kernel association test. Am J Hum Genet 89, 82-93 (2011).

120. Pruitt, K.D. et al. RefSeq: an update on mammalian reference sequences. Nucleic Acids Res 42, D756-63 (2014).

121. Kircher, M. et al. A general framework for estimating the relative pathogenicity of human genetic variants. Nat Genet 46, 310-5 (2014). 
medRxiv preprint doi: https://doi.org/10.1101/2021.03.14.21253553; this version posted March 24, 2021. The copyright holder for this preprint (which was not certified by peer review) is the author/funder, who has granted medRxiv a license to display the preprint in perpetuity. It is made available under a CC-BY-NC-ND 4.0 International license .

IGAP HRC GWAS Meta-Analysis Naj et al.

122. Rentzsch, P., Witten, D., Cooper, G.M., Shendure, J. \& Kircher, M. CADD: predicting the deleteriousness of variants throughout the human genome. Nucleic Acids Res 47, D886-D894 (2019).

123. Kircher, M., Rentzsch, P., Witten, D.M., Cooper, G.M. \& Shendure, J. Combined Annotation-Dependent Depletion (CADD) Annotation Resource.

124. Gamazon, E.R. et al. A gene-based association method for mapping traits using reference transcriptome data. Nat Genet 47, 1091-8 (2015).

125. Barbeira, A.N. et al. Integrating predicted transcriptome from multiple tissues improves association detection. PLoS Genet 15, e1007889 (2019).

126. Battle, A. et al. Characterizing the genetic basis of transcriptome diversity through RNAsequencing of 922 individuals. Genome Res 24, 14-24 (2014).

127. Huckins, L.M. et al. Gene expression imputation across multiple brain regions provides insights into schizophrenia risk. Nat Genet 51, 659-674 (2019).

128. Hoffman, G.E. et al. CommonMind Consortium provides transcriptomic and epigenomic data for Schizophrenia and Bipolar Disorder. Sci Data 6, 180 (2019).

129. Consortium, G.T. The GTEx Consortium atlas of genetic regulatory effects across human tissues. Science 369, 1318-1330 (2020).

130. Denny, J.C. et al. PheWAS: demonstrating the feasibility of a phenome-wide scan to discover gene-disease associations. Bioinformatics 26, 1205-10 (2010).

131. Wei, W.Q. et al. Evaluating phecodes, clinical classification software, and ICD-9-CM codes for phenome-wide association studies in the electronic health record. PLoS One 12, e0175508 (2017).

132. Consortium, E.P. An integrated encyclopedia of DNA elements in the human genome. Nature 489, 57-74 (2012).

133. Ernst, J. et al. Mapping and analysis of chromatin state dynamics in nine human cell types. Nature 473, 43-9 (2011).

134. Rao, S.S. et al. A 3D map of the human genome at kilobase resolution reveals principles of chromatin looping. Cell 159, 1665-80 (2014).

135. Ernst, J. \& Kellis, M. Chromatin-state discovery and genome annotation with ChromHMM. Nat Protoc 12, 2478-2492 (2017).

136. Heinz, S., Romanoski, C.E., Benner, C. \& Glass, C.K. The selection and function of cell type-specific enhancers. Nat Rev Mol Cell Biol 16, 144-54 (2015).

137. Zentner, G.E. \& Scacheri, P.C. The chromatin fingerprint of gene enhancer elements. $J$ Biol Chem 287, 30888-96 (2012).

138. Chesi, A. et al. Genome-scale Capture C promoter interactions implicate effector genes at GWAS loci for bone mineral density. Nat Commun 10, 1260 (2019).

139. BioGPS Portal.

140. Brain RNA-Seq Database.

141. Su, A.I. et al. A gene atlas of the mouse and human protein-encoding transcriptomes. Proc Natl Acad Sci U S A 101, 6062-7 (2004).

142. Lein, E.S. et al. Genome-wide atlas of gene expression in the adult mouse brain. Nature 445, 168-76 (2007).

143. Wu, C. et al. Gene set enrichment in eQTL data identifies novel annotations and pathway regulators. PLoS Genet 4, e1000070 (2008).

144. Zhang, Y. et al. An RNA-sequencing transcriptome and splicing database of glia, neurons, and vascular cells of the cerebral cortex. J Neurosci 34, 11929-47 (2014). 
medRxiv preprint doi: https://doi.org/10.1101/2021.03.14.21253553; this version posted March 24, 2021. The copyright holder for this preprint (which was not certified by peer review) is the author/funder, who has granted medRxiv a license to display the preprint in perpetuity.

\section{It is made available under a CC-BY-NC-ND 4.0 International license .}

IGAP HRC GWAS Meta-Analysis Naj et al.

145. Zhang, Y. et al. Purification and Characterization of Progenitor and Mature Human Astrocytes Reveals Transcriptional and Functional Differences with Mouse. Neuron 89, $37-53(2016)$. 